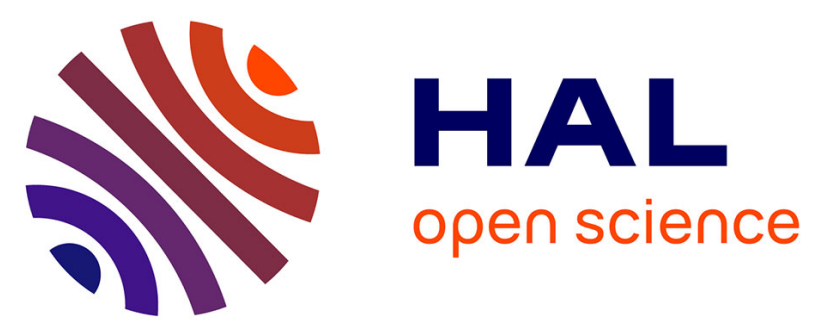

\title{
Interferon-associated therapies toward HIV control: The back and forth
}

\author{
Nicolas Noel, Béatrice Jacquelin, Nicolas Huot, Cécile Goujard, Olivier \\ Lambotte, Michaela Müller-Trutwin
}

\section{> To cite this version:}

Nicolas Noel, Béatrice Jacquelin, Nicolas Huot, Cécile Goujard, Olivier Lambotte, et al.. Interferonassociated therapies toward HIV control: The back and forth. Cytokine and Growth Factor Reviews, 2018, 40, pp.99-112. 10.1016/j.cytogfr.2018.03.004 . pasteur-01969821

HAL Id: pasteur-01969821

https://hal-pasteur.archives-ouvertes.fr/pasteur-01969821

Submitted on 4 Jan 2019

HAL is a multi-disciplinary open access archive for the deposit and dissemination of scientific research documents, whether they are published or not. The documents may come from teaching and research institutions in France or abroad, or from public or private research centers.
L'archive ouverte pluridisciplinaire HAL, est destinée au dépôt et à la diffusion de documents scientifiques de niveau recherche, publiés ou non, émanant des établissements d'enseignement et de recherche français ou étrangers, des laboratoires publics ou privés.

\section{(1)(1) 8 (2)}

Distributed under a Creative Commons Attribution - NonCommercial - ShareAlikel 4.0 


\section{INTERFERON-ASSOCIATED THERAPIES TOWARD HIV CONTROL : THE BACK AND FORTH}

Nicolas Noël ${ }^{1,2,3,4}$, Béatrice Jacquelin ${ }^{1}$, Nicolas Huot ${ }^{1}$, Cécile Goujard ${ }^{2,4,5}$, Olivier Lambotte ${ }^{2,3,4}$, Michaela Müller-Trutwin ${ }^{1}$

1 : Institut Pasteur, Unité HIV, Inflammation \& Persistence, Paris, France

2 : Assistance Publique - Hopitaux de Paris, Service de Médecine Interne et Immunologie Clinique, Hopitaux Universitaires Paris Sud, Le Kremlin-Bicêtre, France

3: INSERM/CEA U1184, Immunologie des Maladies Virales et Autoimmunes, Le Kremlin Bicêtre, France

4 : Faculté de Médecine Paris Sud, Le Kremlin-Bicêtre, France

5 : CESP, INSERM U1018, Le Kremlin Bicêtre, France

\section{Corresponding authors}

-Dr Nicolas Noel, MD, PhD

APHP, Service de Médecine Interne et Immunologie Clinique - Centre Hospitalier Universitaire Bicêtre

78, rue du Général Leclerc - 94275 Le Kremlin-Bicêtre cedex

Phone : +33145212757; nicolas.noel@aphp.fr

-Dr Michaela Müller-Truwtin, PhD

Unité HIV, Inflammation \& Persistance - Institut Pasteur

25-28 rue du Docteur Roux - 75015 Paris

Phone :+331; $\underline{\text { mmuller@pasteur.fr }}$

Count : Abstract 321 words, Manuscript 7172 words, 2 tables, 1 figure, 133 references

Key words : Interferon ; immune activation ; HIV ; cure ; reservoirs 
1. Introduction 6

2. IFN therapy in the early history of the AIDS-pandemics : « A new hope

3. Lessons from IFN-associated therapies during the modern HIV era : " The empire strikes back » 10

3.1. The limit of (Pegylated-)IFN monotherapy: basal ISG production and the viral replication .. 11

3.2. Lessons from clinical trials and studies in HIV1-infected human subjects in the cART era .... 11

3.3. Lessons from IFN-I trials in non-human primate models................................................... 13

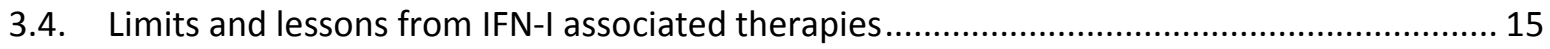

4. Controlling the IFN-induced signalling cascade to control HIV : « The return of the Jed-I »......... 16

4.1. Optimizing the antiviral action of IFN: pre-clinical data of innovative strategies .................. 16

4.1.1. Non- $\alpha 2$ IFN-I subtypes to target anti-HIV infection ........................................................ 16

4.1.2. IFN-I based strategies to control HIV infection at the mucosal surfaces including non- $\alpha$

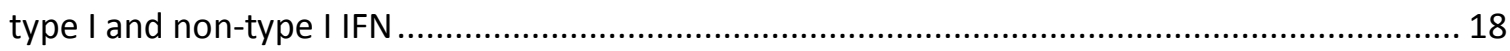

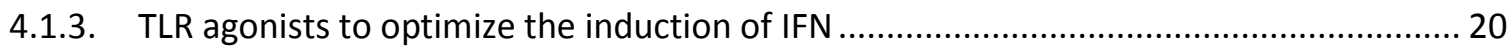

4.2. A revised paradigm : counteracting IFN pathway to control HIV infection ? ......................... 21

4.2.1. Hydroxychloroquine to limit production of IFN : results from clinical trials ................... 21

4.2.2. Anti-INFAR antibodies : results from pre-clinical studies in mice..................................... 22

4.2.3. Anti-JAK-STAT targeted therapies : news from the bench ........................................... 23

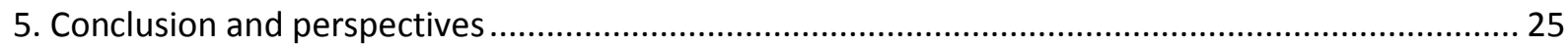


Highlights

- Historical overview of the results obtained with Interferon type I - based therapeutic strategies from the early days of the HIV pandemic up to now

- Lessons drawn from previous Interferon type I - associated pre-clinical and clincial studies

- Overview of innovative strategies for optimizing the antiviral action of IFN-I

- Combination of Interferon type I - based therapeutic strategies with other anti-viral or immunomodulatory agents in the context of HIV cure

- Overview of attempts to counteract IFN-I in view of reducing HIV-induced inflammation 


\section{ABSTRACT}

Human immunodeficiency virus (HIV) induces a persistent and incurable infection. However, the combined antiretroviral treatment (CART) has markedly changed the evolution of the infection and transformed a deadly disease into a manageable chronic infection. Withdrawal of cART generally leads though to resumption of the viral replication. The eradication of the virus from its cellular and anatomical reservoirs remains a goal-to-achieve for a cure. In this context, developing novel therapies contributing to this aim are an important field of research. Type I IFN has antiviral activity, which, before the presence of efficient anti-HIV drugs, has led to the testing of IFN-based therapeutic strategies during the early years of the pandemic. A historical overview of the results and its limitations that were put into light are reviewed here. In addition, several lessons could be drawn. For instance, the efficacy of the IFN-I depends on the timing of its administration and the context. Thus, the persistence of an endogenous IFN-signature, such as that generally observed in viremic patients, seems to be associated with a lower efficacy of IFN. Based on the lessons from previous trials, and in the context of CART and research for a cure, type I Interferon has regained interest and novel therapeutic approaches are currently tested in combination with cART, some with disappointing, other with encouraging results with regard to a reduction in the size of the HIV reservoir and/or delays in viral rebound after cessation of cART. Additional strategies are currently developed in addition to improve the antiviral function of the IFN-I, by using for instance other IFN subtypes than IFN-I $\alpha 2$. In parallel, the development of innovative strategies aimed at counteracting the excessive activation of the IFN-pathways have been continued and their results are reviewed here as well. Altogether, the use of IFN-I in anti-HIV therapies has gone through distinct phases and many lessons could be drawn. Novel combinations are currently be tested that might provide interesting results. 


\section{Introduction}

Since the past 35 years, the human immunodeficiency virus (HIV) is being responsible for a severe pandemic and is currently an incurable infectious disease [1]. This retrovirus infects CD4 expressing cells such as CD4 T cells in the vast majority of cases, but also macrophages and dendritic cells and eventually, at a low rate, other non immune cells such as astrocytes. In the middle of the 1990's, the use of combined antiretroviral therapy (CART) with high efficacy on HIV replication has offered new hopes in the evolution and outcomes of HIV-infected patients. However, cART does not allow for an eradication of the virus for several reasons, including its capacity to persist in a latent form and the residual replication in some tissular sanctuaries (lymph node follicles, brain, gut mucosa, adipose tissue...) in which cART often remains incompletely biodisponible and effective [2-4]. Therefore, active research for additional or alternative therapies to CART allowing the reduction or eradication of HIV reservoirs is a major field of current research in view of strategies toward HIV remission and cure [5].

In this context, the role of Interferons (IFN) as potent anti-HIV weapons has been extensively studied. These proteins were described in 1957 [6] and belong to the first set of cytokines produced after a viral infection. Three families of IFN have been described, namely IFN type I, II and III. In humans, type I IFN comprise 12 subtypes of IFN $\alpha$, and the IFN $\beta, k, \varepsilon$ and $\omega$. The similarities and differences of these different subtypes have been recently reviewed in [7]. The IFN-I family is involved in the regulation of the innate and adaptative immune responses in the setting of viral infections. Type II IFN consists in the single IFN $\gamma$ and is important for its immunoregulatory and inflammatory properties [8]. The type III family comprises IFN $\lambda 1, \lambda 2$ and $\lambda 3$ and is the most recently described $[9,10]$. Its role seems more important in the epithelial-mucosal surfaces to polarize the antimicrobial immune responses [11].

During the first steps of HIV infection, the IFN-Is are mainly produced by plasmacytoid dendritic cells (pDCs) after HIV sensing by toll-like receptors (TLRs, in particular TLR7/9), but also intracellular sensors such as RIG-I or MAVS/STING [12] (Figure 1). Circulating IFN $\alpha / \beta$ then link their common 
receptor (IFNAR) and signal through a JAK-STAT pathway leading to the expression of numerous IFNstimulated genes (ISG) [13]. These ISG participate in the antiviral immune defense by coding for many immunomodulatory factors impacting both innate and adaptive immune cells (such as NK cells and $\mathrm{CD} 8+\mathrm{T}$ cells) and some proteins that might be directly involved in the antiviral response by interfering at multiple steps of the HIV viral cycle $[12,14,15]$.

Due to their potency to modulate the innate and adaptive immunity, type IFN have been developed as therapeutic tools in different conditions. Currently, three main molecules are available : IFNa2a, IFN $\alpha 2 b$, and IFN $\beta$. IFN $\alpha 2 a$ and $2 b$ have been extensively studied in the field of HCV infection until recent direct active antiviral therapies have been approved, relegating IFN to a secondary role in the setting of resistant situations or economic considerations [16]. IFN $\beta$ has been rather employed as an immunomodulatory drug in multiple sclerosis [17]. All these type I subtypes have been shown globally well tolerated. However, some adverse effects such as mood disorders, thyroiditis, anemia, or lung damages might limit their use.

The antiretroviral therapeutic effect of IFN-I has been studied in HIV-infected patients. Different from HCV infection, the benefit of IFN-I on HIV infection is less clear. Indeed, contrasting outcomes have been reported depending on the characteristics of patients at treatment introduction, the associated molecules, but also the readout considered (e.g. control of the viral replication/ the viral reservoirs, preservation/alteration of immune functions, potency to discontinue antiviral therapies...). Also, caveats in the anti-HIV response induced by IFN have progressively come to light, and viral evolution as well as cellular susceptibility might impair the IFN-I response (recently reviewed in [18]). We review here the back and the forth of IFN-associated therapies toward HIV control. 


\section{IFN therapy in the early history of the AIDS-pandemics: «A new hope »}

Before 1996 and the availability of CART, few molecules were shown effective in the fight against HIV but all of them had only a transient effect. Due to his known role as strong antiviral cytokine, the use of IFN alpha as therapeutics has been considered as a new hope to block the pandemic in the early HIV/AIDS era. The first studies evaluated the impact of recombinant IFN $\alpha$ in AIDS-related Kaposi's sarcoma related to HHV8-virus. DeWit et al [19] showed the reduction of plasma HIV-p24 antigen in seven responders out of 28 patients treated with high-dose IFNa2a (subcutaneous injections, 27-36 MU daily for 8 weeks). Lane et al [20] reported similar changes in circulating levels of p24 antigen in 8 out of 21 patients treated with IFNa2b (35 MU daily during 12 weeks, possible dose-reductions depending on the tolerance) with KHSV-AIDS. In these two studies, recombinant IFN was used as monotherapy in immunocompromised patients with AIDS-related severe comorbidities. In 1990, the study by Lane et al [21] evaluated for the first time in a randomized, double-blind trial the early administration of IFN $22 \mathrm{~b}$ ( $35 \mathrm{MU} / \mathrm{d}$ for 12 weeks) vs. placebo in $34 \mathrm{HIV}$-infected patients. This therapy was globally well tolerated except for neutropenia and flu-like symptoms in a dosedependent manner. Also, Rivero et al evaluated the benefit of IFNa2b ( 3 million IU, 3 times a week) during the early stages of infection [22] in 71 HIV-infected patients vs. 79 on placebo. The endpoints were the appearance of any CDC group IV symptoms and disease progression. Overall, IFN $\alpha$ therapy allowed for a reduction of the proportion of patients meeting these endpoints. Development of AIDS was observed in $12 / 71$ patients on IFNa2b vs. $27 / 79$ control patients. Moreover, the long-term evaluation of these patients [23] revealed prolonged benefit of IFN $\alpha 2 \mathrm{~b}$ on event-free periods, leading to a question of the timing: could IFN $\alpha$ treatment given from the early stage of infection - but not after the appearance of AIDS symptoms - prolong survival ?

However, the beneficial potential of IFNa2 therapy in HIV/AIDS was limited by the side-effects of this therapy. Since 1988, Lane et al already noted that although encouraging, their results on KHSV-AIDS patients had to be interpreted with caution. Responders were patients with preserved immune 
functions (CD4 count $>500 / \mathrm{mm}^{3}$ ) after a long term IFN-therapy. Moreover, the tolerance of highdose IFN $\alpha$ was bad, with congestive cardiomyopathy, flu-like symptoms and cytopenias leading to withdraw therapy in nine out of 21 patients [20]. These effects were presumably heightened by a reduced bioavailability and the need of high doses with adverse immunological and clinical consequences, as shown by Skillman DR et al [24] in a study evaluating the safety of recombinant IFNan3 (biosynthetized after stimulation of pooled human leucocytes with Sendai virus) in early stages of infection.

Studies with IFN $\beta$ were also developed as an alternative to IFN $\alpha$ therapy. In the late 80 's, association of IFN $\beta$ with zidovudine revealed promising effects on the reduction of HIV p24 in vitro [25]. Moreover, this study suggested synergic action with AZT allowing for a reduction in the dose of zidovudine to limit side effects. Michaelis et al also suggested that IFN $\beta$ could block HIV replication in vitro at low doses (limited to $100 \mathrm{U} / \mathrm{mL}$ in vitro) [26]. However, these results were not confirmed in vivo in studies evaluating the effect of IFN $\beta$ monotherapy at low doses (1 million IU twice a week, [27]) in early stages of the infection. In the setting of Kaposi's sarcoma, high dose IFN $\beta$ monotherapy (90 to 180 million IU/d, 5 days a week, [28]), as well as low dose IFN $\beta$ (6 million IU/m2 three times per week) associated with IL-2 [29], or even dose-escalation therapy (22.5-45-90 million IU daily) with zidovudine [30], did not lead to major effects on the tumor size as well as on the overall survival, although transient reduction of HIV viral load were observed. However, the reported tolerance seemed better that the one of IFNa2 (but no studies compared both therapies).

In most of these studies, summarized in Table 1, the use of IFN-I as monotherapy has shown his potency to reduce the burden of HIV, but the impact was moderate ( 1 to 2 log HIV RNA copies/mL) and transient (a couple of months maximum). These early studies also already revealed some of the major limits of its use, in particular the risk of CD4 T cell loss when high doses of IFNa were used. Also, these studies showed very limited improvement in terms of overall survival, maybe because of the already-late stage of the infection for the majority of the included patients. Finally, the landscape 
of the HIV pandemic was profoundly transformed in the mid-1990's thanks to the development of the highly-active antiretroviral combinations with rapid, robust and durable effects on both the immunovirological control and the overall clinical outcome of the patients, leading to transiently interrupt the development of IFN-based therapies for HIV/AIDS patients.

\section{Lessons from IFN-associated therapies during the modern HIV era : "The empire strikes back»}

During the CART era, the outcome of HIV-infected patients has progressively improved with therapeutics allowing for a highly efficient and persistent control of the HIV replication, a significant regain of CD4 T cells and an extraordinary increase in lifespan. A number of studies from the early 2000's evaluated the impact of standardized therapeutics' interruptions (STI) as a measure for reducing drug toxicities, decreasing costs and increasing welfare in people living with HIV (PLWH) in terms of adverse events and control of the viral load. However, it rapidly became clear that these regimens could not be withdrawn without any resumption of the HIV viral load due to the existence of the HIV reservoirs and sanctuaries [31-33]. Thus, even highly active, cART could not easily access some tissues and infected cells in a latent state, responsible for a reseeding of the HIV burden in case of ART cessation [2,33]. In this context, the adjunction of IFN-I to combined ART has been investigated with various outcomes. However, one limit of the wide use of recombinant IFN reported in the earlier studies was the adverse side effects, which were mainly dose-dependent. The development of pegylated molecules (PEG-IFN) revealed more favorable pharmacokinetic and safety profile than previously available IFN $\alpha$ formulations in the setting of HCV and HBV infections and were tested in HIV-infected patients [34,35].

If - globally - the effects were not as positive as expected, the issues and limits raised by these studies are of peculiar interest to improve the further design and rationale of IFN therapeutic use. 


\subsection{The limit of (Pegylated-)IFN monotherapy: basal ISG production and the viral replication}

In 2010, Asmuth et al reported on the effect of PEG-IFNa monotherapy in eleven chronically infected HIV1-patients treated during 12 weeks [36]. The aims were to limit side effects by using the PEGmolecule rather than high-dose recombinant IFNa, and to detect changes in the plasma HIV viral load. The authors also sought to correlate the effect with the concentration of the PEG-molecule. These patients were ART-naïve with a viral load $>5000$ copies $/ \mathrm{mL}$ at enrollment, but not severely immunocompromised (CD4 $>300 / \mathrm{mm}^{3}$ at baseline, no AIDS-defining illness), contrasting with previous studies. A decrease in viral load was observed during therapy, with no sustained response after withdrawal. The most interesting result was that this decrease was correlated with the potency of ISG induction, but not with the PEG-IFN plasma concentrations. Also, no response was observed in patients who had a baseline elevated ISG-expression. Probably the existence of an elevated « basal state » of ISG expression prevents from the possibility to further increase their expression, suggesting that a fold-increase in the antiviral response was not achievable in patients with persistent chronic inflammation. The patients with chronically elevated ISG expression had probably reached a state of tolerance against IFNa. This could explain the only transient impact on viral load in this study as in the previous ones. In addition, it has been shown that HIV can escape from IFN $\alpha$ and evolve into IFN-I resistant strains [37]. In chronically HIV-infected patients, high basal levels of ISG expression has been linked with intense viral replication in ART-naïve patients, which nowadays cannot be considered as good candidate for IFN trials, as stated above. Since the level of inflammation during HIV infection strongly correlates with viral load, the lesson taken was that IFN-I should be rather administered in virologically suppressed patients.

\subsection{Lessons from clinical trials and studies in HIV1-infected human subjects in the cART era}

Between 2000 and 2012, the use of IFN was considered as an adjunct therapy during successive treatment interruption (STI)-periods to limit the rebound in HIV replication. In 2008, Dianzani et al 
studied HIV1-HCV-coinfected patients controlled on CART, in which PEGylated-IFN $\alpha$ was given during the planned drug-free periods [38]. Interestingly, a reduction of the magnitude of viral rebound as well as a delay in the rebound was observed. However, no significant effect on HIV-DNA - a measurement used to assess the size of the HIV reservoir - was observed in the IFN group, and the HIV replication returned to similar levels than patients in the control group. The INTERVAC-ANRS 105 trial, published in 2011, was the first randomized controlled trial evaluating the impact of PEG-IFNa during STIs [39]. This study enrolled 168 HIV1-infected patients, with planned STI-periods (twelve weeks on ART followed by a four week interruption, three courses), associated or not with a 4-weekPEG IFN $\alpha$ therapy during STI ( $n=84)$. The follow-up was planned between week 48 and 72 , and the primary endpoint was the occurrence of a criteria for treatment resumption at week 72 (VL > 30000, CD4<350). No significant difference was observed between the two groups. Moreover, a detrimental effect in the IFN arm was observed when patients had low CD4 T cell counts and/or high HIV-DNA levels at baseline.

Also, the INTERPRIM-ANRS 112 trial [40] compared three strategies in HIV1-infected patients diagnosed during primary HIV infection ( $n=91$ ): cART during 72 weeks continuously, vs. cART during 36 weeks followed by planned STIs, vs. cART + PEG-IFNa2b injections during 36 weeks followed by planned STIs in which PEG-IFN injections were given. In all patients, therapy was discontinued at week 72 with the aim to observe the kinetics of T cell counts, HIV RNA and HIV DNA evolution until week 96. Antiviral effects of IFN could be observed on HIV replication (lower HIV viremia during rebounds in the ART-STI-IFN group during each of the three cART interruption), without any impact though on the HIV DNA. Predictive factors of virological outcome were HIV-RNA and HIV-DNA levels at PHI and HIV-DNA levels at treatment interruption. Overall, no better outcome was observed in the IFN group since at the end of the follow up ( 6 months after the last treatment interruption), all virological readouts were similar between the groups. The authors concluded that it might be possible that the administration of IFN during periods with active viral replication could have masked its role as an adjunctive treatment to ART in the search for HIV cure. 
Subsequent studies have investigated IFN as a weapon against the HIV reservoirs in association with active cART. Azzoni et al reported a proof-of-concept clinical trial in which 23 treated and virologically suppressed patients were randomized to receive PEG-IFNa2a as an add-on therapy to CART during five weeks before CART withdrawal [41]. PEG-IFN was continued until week 12 to 24 as monotherapy. They showed that in some patients, PEG-IFN could induce a decrease in the HIV-DNA levels in CD4 T cells, thus indicating for the first time a positive effect on the reduction of the HIV reservoir. These results were supported by studies in HCV/HIV co-infected patients, in which HIVDNA levels decreased during periods on cART associated with IFN+ribavirine therapy $[42,43]$.

\subsection{Lessons from IFN-I trials in non-human primate models}

Some fundamental clues regarding the role of IFN-I in HIV infection came from studies in non-human primate models (review in $[44,45]$ ). In particular, disease-susceptible macaques experience chronic inflammation similar to PLWH when infected with SIVmac, including strong ISG responses. In contrast, natural hosts of SIV, such as African green monkeys (AGM) and sooty mangabeys (SM), resolve chronic inflammation at the end of acute infection and are protected against disease progression [46-48]. If IFN-I was hold responsible for the ISG induction and/or contributes significantly to chronic inflammation, one could think that an IFN-I treatment in natural hosts might lead to an increase of the signs of a deleterious immune activation and disease progression. Two studies tested this hypothesis by injecting high doses of recombinant IFNa during either the acute or chronic phase of SIV infection in AGM and SM, respectively $[49,50]$. For the study in the acute phase, recombinant simian IFN $\alpha 2$-IgFc was administered starting from the day of endogenous peak of IFN $\alpha$ until the day 9 to 24 post-infection (p.i.) to maintain high IFN $\alpha$ levels throughout the acute phase of infection. For the study in chronic phase, the same IFNa molecule was administered weekly for 16 weeks. A strong ISG upregulation and a 1-log decrease in HIV viremia persisting through day 35 of treatment was observed when the treatment was given in the chronic phase, but not in the acute phase. This suggests that the animals are not reactive to exogenous IFN $\alpha$ when administered in late acute infection after the peak viremia. Moreover, the IFN treatment whether in acute or chronic 
phase, had no major impact on immune activation and nor pathogenesis. These studies suggested that in untreated SIV infection: (i) IFNa levels are already high during acute infection and cannot be significantly increased through exogenous administration when administered after the eclipse phase, (ii) a state of tolerance against exogenous IFNa is induced after several weeks or months of treatment, similar to what has been observed in humans infected by HIV, (iii) to study if IFNa has a long term impact on inflammation and disease progression, several rounds of intermittent treatments for long periods would probably be necessary and (iv) high levels of IFNa in acute infection are not solely responsible for the harmful inflammation observed in pathogenic HIV/SIV infections.

The opposite approach, i.e. treating SIV-infected macaques with an antagonist of IFNAR to block IFN $\alpha$ action was also studied [51]. The antagonist was administered during the first four weeks of infection. This treatment revealed to be detrimental because it reduced antiviral gene expressions, increased SIV reservoir size and accelerated CD4 T-cell depletion with progression to AIDS [51].

Collectively, these data suggest that IFN-I signaling early in SIV infection is critical for innate immune control of virus replication. Based on these findings, it was hypothesized that very early IFN-I therapy could improve the viral control. Macaques were treated with pegylated IFN $\alpha 2 a$ starting 1 week before challenge until 4 weeks p.i. [51]. Treatment significantly reduced susceptibility to infection. However, the animals that got infected despite treatment with IFN $\alpha$ before challenge showed a worse outcome characterized by increased CD4 T-cell-associated virus load and greater CD4 T-cell loss with preferential depletion of the $\mathrm{CCR}^{+}$subset. This might be explained by the state of tolerance toward IFN-I induced in a critical phase of infection.

All these studies highlighted that the impact of IFN-I treatment on the infection strongly depends on the timing of administration and the level of control of inflammation in the environment in vivo. 


\subsection{Limits and lessons from IFN-I associated therapies}

Altogether, these studies show that the use of IFN might have some beneficial effects and that the contrasting outcomes reported depend on many distinct factors. As stated above, the first one is the timing of the treatment: IFN-based therapies seem to have better impact on the early phases of the infection, before the occurrence of excessive inflammation and immunodepression [51]. A second factor if the magnitude of viral replication at time of IFN-I administration $[39,40]$. The administration of IFN during periods of intense viral replication might be responsible for the weak impact of this strategy [40], perhaps due to the existence of IFN resistant strains [37]. In line with this, the third factor to be taken into account if the level of persistent inflammation. Virological suppression could reduce systemic inflammation and increase the susceptibility to IFN-I treatment [36]. However, ISG expression might remain relatively elevated in a few patients with undetectable viral loads (on therapy or in HIV-controllers) [52-56]. In these settings, the role of non-measurable HIV replication in lymph nodes and tissues, as well as other sources of immune activation (such as microbial translocation, co-infection with hepatitis viruses, cancer...) must be taken into account in designing the trials $[55,57,58]$. Another factor concerned the fact that the effects of IFN-I depended on the cell type and its differentiation/activation state. For example, chronic HIV infection might reduce the expression of IFNAR at the membrane surface leading to desensitize cells to IFN [59]. Also, negative regulation of the IFN-IFNAR signaling pathway downstream of the receptor has been suggested, due to the induction of SOCS1/3 [59-61], or other negative regulators such as Foxo3a [51]. Lastly, latently infected cells might be less responsible to IFN, with significant impairment in the induction of potent antiretroviral ISG, although these data have to be confirmed on human primary cells [62].

While it appears that IFN plays a beneficial role in the early antiviral battle against HIV, the benefit of the use of IFN-I in therapy is still uncertain and clearly needs additional studies with improved experimental design based on the high number of lessons gained from the previous trials. 


\section{Controlling the IFN-induced signalling cascade to control HIV : «The return of the Jed-| »}

Another important goal to achieve is to optimize the balance between the enhancement of the immune response and the deleterious induction of excessive systemic inflammation. In this context, reflexions has been conducted in the recent years on how to improve efficacy of IFN-I, including (i) the use of non-alpha2 subtypes during HIV infection, (ii) the induction of endogenous production of IFN by modulating the HIV-sensors and (iii) the modulation of IFN-pathways by hydroxychloroquine, anti-IFNAR and anti-JAK/STAT strategies. These distinct strategies, currently developed in pre-clinical and sometimes clinical models, will be discussed below.

\subsection{Optimizing the antiviral action of IFN: pre-clinical data of innovative strategies}

\subsubsection{Non- $\alpha 2$ IFN-I subtypes to target anti-HIV infection}

As mentioned above, IFN-I does not only consist in $\alpha 2 \mathrm{a} / \mathrm{b}$ or $\beta$ types. In humans, twelve $\alpha$ subtypes have been described ( $\alpha 1, \alpha 2, \alpha 4, \alpha 5, \alpha 6, \alpha 7, \alpha 8, \alpha 10, \alpha 14, \alpha 16, \alpha 17, \alpha 21)$ [63]. These subtypes are encoded by separate genes on human chromosome 9 and all bind to the same IFN receptor. It is not totally clear how the signaling could differ from one subtype to the other despite the use of a same receptor. There is evidence though that each subtype has a different binding capacity to the IFNAR [64,65], modulating the signaling transduction events and the biological effects in the target cells. In non-HIV condition, the distinct efficacy of the different $\alpha$ subtypes has been described in mice models of HSV, influenza or CMV [66-68]. Recently, the impact of distinct IFN alpha subtypes has been investigated in vitro in the field of HIV. Harper et al [69] showed that the anti-HIV potency of the IFN $\alpha$ subtypes was distinct in a model of human intestinal cell culture in vitro. Thus, IFNa8, $\alpha 6$, $\alpha 14$ and $\alpha 17$ reduced the infection capacity of the cells better than the commercially available IFNa2 and the widely expressed IFNa1. This potency was correlated with the binding affinity to IFNAR2 and the capacity to induce ISG known to restrict HIV (Mx2, BST2). One step further, Lavender et al [70] confirmed the significantly greater impact of IFNa14 over IFN $\alpha 2$ to suppress the HIV1 replication in vivo in a model of TKO-BLT mice treated with these subtypes. This was associated with the induction 
of BST2 and Mx2 and a higher frequency of TRAIL-expressing NK cells. Interestingly, the mice not only had less viral replication but also less inflammation as measured by IP10 quantification at 11 and 45 days p.i..

Non- $\alpha 2$-subtypes therapeutic strategies are limited by the difficulties to produce these molecules because of their extensive sequence homology. This has led to gene therapy strategies using plasmids encoding IFN $\alpha 2, \alpha 6, \alpha 8, \alpha 14$ and IFN $\beta$ in a model of humanized PBL-mice [71]. The injection of such plasmids to the mice before infection by HIV1 led to an effective control of the viral replication by IFN $\alpha 14$ and IFN $\beta$.

Overall, these studies lead to imagine that one novel direction of the IFN-based therapy could be the development of non- $\alpha 2$ subtypes with a stronger antiviral impact on HIV. Especially, IFNa14 seems interesting in that respect. However, the question of the excessive immune activation and/or immune tolerance induction, cellular exhaustion and CD4+ T cell loss in case of therapeutic exposure to these subtypes is not known and might be raised.

One question that also remains is the "competition " between the endogenous circulating IFN $\alpha$ subtypes. Several studies have addressed the quantification of the distinct IFN-I subtypes in HIV and SIV infections [72-75]. These approaches remain however difficult due to the limit of available quantification technologies to correctly distinguish the sequences displaying high homology and the lack of specific antibodies against each of the distinct subtypes. The improvement of methods able to measure the multiple subtypes is warranted to take into account their basal production in the conception of IFN-based strategies. Also, the question of the potential competition on IFNAR between endogenous IFN and the exogenous administration of the molecule remains unadressed. Finally, until recently, the dosage of IFN-I in the blood during chronic infection has been difficult due to the lack of sensitive methods for IFN-I measurement. New approaches such as the ultrasensitive quantification by single-molecule array digital ELISA technology (SIMOA) will be helpful in future studies on HIV [76]. 


\subsubsection{IFN-I based strategies to control HIV infection at the mucosal surfaces including non- $\alpha$ type I and non-type I IFN}

IFN $\alpha / \beta$ has been administered by systemic subcutaneous injections in all studies published in the setting of HIV-infection in humans. We have mentioned above the limitation of the drug doses by systemic adverse side effects such as thyroiditis, lung damages, mood disorders and cytopenias. Targeting the innate mucosal immune responses by topical treatments without excessive systemic side effects might thus be interesting. Indeed, the mucosal transmission and the alteration of the epithelial-mucosal surfaces in the early steps of HIV infection play major roles in the pathophysiology of the infection. In this context, Veazey et al evaluated the impact of topical IFN $\beta$ treatment applied to the vagina of Rhesus macaques before intravaginal challenge with pathogenic SHIV [78]. This allowed for a significant prevention from vaginal SHIV transmission, with local induction of T-cell activation and the recruitment of macrophages. Interestingly, no difference in the expression of activation markers such as CD38 or HLA-DR were noted in the peripheral blood T cells [77]. This contrasts with the outcome of an intravaginally treatment with either a TLR7 or TLR9 agonist before viral challenge, which was not sufficient to prevent infection [78]. While both immune modifiers rapidly induced IFN $\alpha$, they also resulted in multiple other types of immune activation, including massive infiltration of activated CD4+ $\mathrm{T}$ cells and dendritic cells, which might have enhanced susceptibility to infection.

IFN $\varepsilon$, another IFN-I, is constitutively expressed in the female reproductive tract and contributes to the immune protection against sexually transmitted infections [79]. Similar to other IFN-I, it is encoded by a gene on human chromosome 9 . The protein then binds to IFNAR with a striking affinity preference for the IFNAR1 subunit, and enhances the canonical JAK-STAT1 signaling to induce the expression of ISG [80]. It has recently been shown that IFN $\varepsilon$ could impair cellular infection by HIV at different steps of the viral cycle (post-entry, protein translation) by induction of restriction factors such as IFITM3 in distinct cell lines as well as human peripheral lymphocytes in vitro $[80,81]$, and might reduce the primary macrophages susceptibility to HIV infection [82]. 
Another interesting IFN acting at the step of mucosal surface infection is type III IFN $\lambda$. The family of IFN $\lambda$ comprises three entities, namely IFN $\lambda 1$ (IL29), IFN $\lambda 2$ (IL28A) and IFN $\lambda 3$ (IL28B). All these members are structurally common to the IL10 family and act through the binding to a heterodimeric receptor comprised of IFN $\lambda$ R1 and IL1OR2 to induce the activation of JAK-STATs and the expression of ISG [9-11]. The induction of type III IFN following viral infection is globally similar than type I, but some distinctions exist in the fact that the STING-peroxysomal sensing plays a greater role in type III induction. Also, type III IFN are produced more abundantly at mucosal sites by epithelial and myeloid cells $[83,84]$. Moreover, while IFN-I is generally produced in largest amounts by plasmacytoid dendritic cells during HIV infection, the expression of IFN $\lambda$ R1 is more restricted to epithelial cells, subsets of myeloid cells such as macrophages, and neuronal cells [85]. This confers a greater potential for the antiviral response of IFN $\lambda$ at the mucosal surfaces. So far, analyses on the impact of IFN $\lambda$ on HIV infections are limited to in vitro studies. IFN $\lambda 1, \lambda 2$ and $\lambda 3$ exposure of human monocytederived macrophages limited HIV infection through activation of the JAK-STAT pathways [86-88]. Exposure of human primary CD4 T cells to IFN $\lambda 1$ or $\lambda 2$ reduced HIV infection at integrational and posttranscriptional steps [89]. Interestingly, activation of endothelial cells by poly I:C was able to diminish HIV infection of human macrophages in coculture models, by inducing IFN $\lambda$ production by endothelial cells and ISG expression by macrophages [90], opening an interesting view for a potential anti-HIV activity at the blood-brain-barrier. Lastly, it has been shown that IFN $\lambda$ could efficiently inhibit macrophages infection by HIV and enhance the antiviral activity of antiretroviral drugs such as zidovudine or efavirenz [91].

Overall, IFN $\lambda$ seems to be an interesting tool to enhance the anti-HIV immune responses at mucosal surface and the blood-brain-barrier. It would be interesting also to evaluate its capacity to reduce the infection of macrophages and in general to prevent the reseeding of HIV reservoirs. Of note, PEGylated IFN $\lambda 1 \mathrm{a}$ is available and has been investigated as a therapy for HBV/HCV infections in humans $[92,93]$. No approval has been currently given by the FDA, and an evaluation is ongoing for the treatment of hepatitis delta virus infection. Only one study has explored the addition of 
PEGylated IFN $\lambda$ in the setting of HIV/HCV coinfection with no specific focus on the anti-HIV response and the reduction of the HIV reservoirs [94].

\subsubsection{TLR agonists to optimize the induction of IFN}

Due to their role in induction of type I interferon after RNA triggering, TLR agonists have been investigated in the setting of HIV infection. This might also be, as mentioned above, an interesting approach to avoid competition between exogenous and endogenous IFN, and also has additional effects on immune activation, that could be both harmful and beneficial. Their use is actually revisited in the context of cART and development of cure strategies as well as vaccines.

Distinct TLR7 agonists are currently tested. Imiquimod is a TLR7 agonist with known anti-HSV and anti-HPV efficacy, used by topical administration in the setting of anogenital warts in HIV immunocompromized patients $[95,96]$. Resiquimod, a TLR7/8 agonist also known as R848, has been shown to restrict HIV1 infection of monocytes in a post-entry/pre-reverse transcription SAMHD1independent manner [97]. Together with other molecules, this TLR agonist might serve as adjunct for vaccine strategies in order to elicit antiviral immune defenses against HIV $[98,99]$. The TLR7 agonist GS-9620 (Vesatolimod) is currently being evaluated in HBV and HIV infections. This orally administered molecule takes the advantage over imiquimod and resiquimod with respect to systemic diffusion. In vitro, GS-9620 is able to activate pDCs and to induce IFN [100], as well as to inhibit human CD4 T cell infection by HIV1 in a coculture model with GS-9620-exposed pDCs [101]. GS-9620 increased HIV replication in infected cells from ART-suppressed patients, enhanced T cell activation and antibody-mediated clearance of infected cells in vitro, thus providing interesting clues for strategies targeting latently infected cells [102]. TLR7 agonists are thus currently tested, eventually in combination with other immunomodulatory agents, for their capacity to drive latent HIV out of viral reservoirs while enhancing concomitantly virus-specific immune responses.

TLR9 agonists, such as MGN1703 (lefitolimod) have also been shown to enhance HIV-1 transcription as well as NK cell-mediated inhibition of infected CD4 T cells [103]. In a single-arm, open-label study, MGN1703 was subcutaneously administered twice weekly (60mg per injection) to 15 virologically 
suppressed HIV-1-infected individuals on antiretroviral for 4 weeks. The tolerance was correct and MGN1703 allowed for the enhancement of cytotoxic NK- and CD8 T cell responses, together with an increase in the HIV viral load in $6 / 15$ patients. The authors conclude on the potential interest of TLR9 agonist against HIV reservoirs by increasing HIV-1 transcription and enhancing cytotoxic NK cell activation [104]. Moreover, colonic biopsies from these patients have been analyzed. An interesting enhancement of the type I interferon response at the mucosal site has been observed, without concomitant local inflammatory response and mucosal damages [105].

Overall, TLR agonists confer encouraging results to further evaluate their use in vaccine strategies and the battle against HIV reservoirs. Studies are ongoing to evaluate the safety of GS9620/vesatolimod in ART-controlled patients and HIV-controllers (NCT02858401 and NCT03060447). Also, the efficacy of MGN1703/lefitolimod to activate NK cells and reverse HIV latency is being investigated in a phase $1 / 2$ study in HIV1 ART-treated patients (Table 2).

\subsection{A revised paradigm : counteracting IFN pathway to control HIV infection ?}

It is well known that even in virologically suppressed PLWH, a residual inflammation persists. Systemic inflammation is associated with a default in CD4 T cell recovery, a risk of blips of HIVreplication as well as increased non-AIDS comorbidity and mortality [106-110]. Such residual inflammation can also be observed in HIV controllers, and those with a higher residual inflammation have a higher risk of virological relapse $[54,111]$. It thus seem relevant to target the chronic activation and one target currently still approached is the IFN pathway to reduce the IFN-associated inflammation. There are globally two major ways to counteract the effect of the IFN : (i) to limit the induction by IFN-producing cells and (ii) to limit the signaling transduction in the target cells.

\subsubsection{Hydroxychloroquine to limit production of IFN : results from clinical trials}

Hydroxychloroquine (HCQ) is an endomosal inhibitor of TLR7 and TLR9, initially developed as an antimalarial drug in the 1950's [112]. It has extensively been studied in rheumatic autoimmune disorders with chronic IFN-signature such as systemic lupus erythematosus [113] and in some viral infections with post-viral arthritis mediated by IFN such as chikungunya virus [114]. It has an 
extremely good safety profile. Due to his potency to block TLR activation in pDCs and to reduce IFN production in vitro [115], its use for the modulation of the excessive IFN-signature in the setting of HIV has been considered. Murray et al confirmed at an in vivo step the potential role for HCQ to reduce excessive T cell activation in 13 infected patients [116]. This led to the hypothesis that HCQ could serve as an adjunct therapy in immunological non-responder patients, who exhibit excessive chronic activation limiting CD4 T cell recovery. Piconi et al reported on 20 HIV-infected immunologic non-responders treated with $400 \mathrm{mg} / \mathrm{d}$ hydroxychloroquine during 6 months, with positive results on immune activation, plasma LPS levels and \% CD4 T cells [117]. However, Routy et al failed to demonstrate such an effect in 19 HIV-infected patients with persistent low CD4 T cells on efficient long-term ART [118]. Surprisingly, a significant rise in circulating IFN $\alpha 2$ levels was even observed during $\mathrm{HCQ}$ exposure. Paton et al also evaluated the potency of $\mathrm{HCQ}$ to limit the CD4 cell decrease in a double blind randomized controlled trial in 81 untreated HIV1-infected patients. The authors showed that the use of HCQ compared with placebo did not reduce CD8 cell activation but did result in a greater decline in CD4 cell count and increased viral replication in viremic patients [119].

Overall, the encouraging in vitro data on the impact of HCQ to limit IFN-associated inflammation and its consequences were not confirmed in vivo. Studies evaluating the effect of HCQ in combined strategies to limit immune activation or to control HIV replication are ongoing (Table 2).

\subsubsection{Anti-INFAR antibodies : results from pre-clinical studies in mice}

Aside from preventing the production of IFN by innate immune cells, another method to counteract the excessive immune activation associated with chronic IFN stimulation is to target the signalling cascade on target cells. In the first days of 2017 , two teams published on the targeting of type Imediated activation in humanized mice models of HIV using IFNAR antagonists to restore immune functions and reduce HIV reservoirs [120,121] (editorial by Deeks et al [122]). Zhen et al [120] used an anti-IFNAR2 antibody in a NSG-BLT humanized mouse model challenged with HIV1. As expected, ISG expression was reduced as well as CD8 T cell exhaustion (PD1, TIM3) and activation markers (CD38). Moreover, IFNAR blockade effectively reduced the HIV viral load in the chronic stage of the 
infection, and the association with cART resulted in a faster viral suppression and reduced levels of inducible viral reservoirs. Similarly, Cheng et al [121] used an anti-IFNAR1 antibody in NRG-BLT humanized mice. CART were introduced 4 weeks after HIV1 challenging and anti-IFNAR1 were administered after seven weeks. CART were then interrupted after 12 weeks p.i. This strategy showed a correct preservation of the CD4 T cell count along with a restoration of CD8 functionality. Moreover, cell associated HIV-DNA decreased and viral outgrowth assays showed reduction of the HIV inducible reservoirs after cART cessation.

Altogether, these studies showed promising results on the ability of IFNAR blockade to relieve chronically activated T cells to a most quiescent state and restore their ability to fight against HIVinfected cells. Anifrolumab is a monoclonal anti-IFNAR1 antibody currently developed in autoimmune diseases [123]. No clinical trial has been registered to evaluate such a strategy in HIV1-infected humans.

\subsubsection{Anti-JAK-STAT targeted therapies : news from the bench}

The JAK/STAT pathway is early and chronically activated in immune cells during HIV infection, partly due to the engagement of IFN in their target cells but also to the production of numerous cytokines in patients who already experience high levels of systemic inflammation [124-126]. This activation in infected CD4 T cells and macrophages may be responsible for the increased viral production as well as potent reversal of latency and reactivation of the virus in reservoir cells. Also, the JAK/STAT action in other immune cells participates in the recruitment of target cells to virus-producing sites, activation of the immune system, production of inflammatory cytokines such as IL6 of TNF $\alpha$, and end-organ damages such as cardiovascular events, neurocognitive disorders and gut-immune dysfunction [107-109]. In the field of HIV, JAK1/2 inhibition is interesting by its ability to reduce systemic inflammation. However, JAK3 inhibition might be associated with off-target significant toxicity since it has been shown that administration of anti-JAK3 in macaques during SIV infection were associated with NK cell depletion and increase in the HIV viral loads $[127,128]$. 
There are currently three available JAK1/2 inhibitors (JAKi) approved in different settings. Ruxolitinib (Jakafi*) is a JAK1/2 inhibitors FDA- and EMA-approved for myelofibrosis and polycythemia vera. Tofacitinib (Xeljanz*), is a JAK1/2 inhibitor approved for rheumatoid arthritis by the FDA and the EMA, and for psoriatic arthritis by the FDA. Baricitinib (Olumiant*) is a JAK1/2 inhibitor EMAapproved for rheumatoid arthritis (waiting for the final FDA approval concerning doses and safety characteristics). All three are oral selective and well tolerated molecule inhibitors.

In 2014, Gavegnano et al [129] reported on the potent utility of ruxolitinib and tofacitinib to limit HIV-1 replication and reactivation in vitro. Both drugs were able to reduce infection of human primary lymphocytes and macrophages by HIV-1 and HIV-2 strains, including NRTI-resistant strains. Combination of the drugs allowed for a more potent antiviral activity, and viability of the cultured cells remained correct except for very high drug concentrations. These findings were confirmed for ruxolitinib in a murine model of HIV encephalitis [130], suggesting an interesting role by crossing the blood-brain-barrier to fight against HIV-reservoirs in the brain sanctuary. Also, it has been suggested that JAKi could confer peculiar interest in limiting inflammation in association with latency-reversal agents in a "shock-and-kill » strategy model. Spivak et al [131] thus showed that ruxolitinib was able to limit the production of IL6, TNF $\alpha$, IL1 $\beta$ and IFN $\gamma$ by PBMCs exposed to the PKC agonist ingenol3,20-dibenzoate without affecting the HIV1-reactivation capacity of the LRA. This study suggested that JAKi had different mechanisms to regulate the inflammation and to control the HIV1 latency. Finally, Gavegnano et al [132] recently demonstrated that JAKi were able to limit the infection of bystander cells by reducing the immune activation in a PSTAT5-dependent manner, and allow for an accelerated reduction of the overall size of the $\mathrm{VIH}$-reservoir by interfering with the infected T cells lifespan by reducing Bcl2 expression.

Overall, these data reinforce the interest in JAKi for testing its efficacy on diminishing the reseeding of the HIV reservoirs. Ruxolitinib is currently being tested in a phase 2 international randomized 
control trial (NCT02475655) in association with CART for evaluation of the safety and impact on the viral suppression and CD4 T cell counts in HIV1 infected patients (Table 2).

\section{Conclusion and perspectives}

Altogether, these studies show that strategies targeting the IFN pathway during HIV infection can be optimized (Figure 1). Close collaborations between physicians and bench scientists might improve the knowledge of the IFN signalling and regulation, as well as the management of IFN-based therapies in the setting of HIV infection, giving clues to future directions in clinical trials and studies.

A better personalized selection of the "candidates" for the IFN-a2 based strategies strategies might also improve the efficacy of these studies. Thus, IFN-based therapies might lead to better results in patients with low immune activation, as in association with cART in virologically controlled patients. Also, the use of recently-described alternative IFN subtypes might improve the antiviral control, including at mucosal sites. An improvement in the imbalance between antiviral activity and inflammation induced by the IFN pathways should though to be aimed in the future, and the impact on inflammation by approaches such as with non- $\alpha 2$ IFN subtypes in combination or not with other agents will need to be tested.

On the opposite, immunological non-responders and patients with excessive basal IFN-signature despite viral control on ART most likely will not benefit from simple IFN-a2 based strategies. Such patients with persistent systemic inflammation also include patients with inflammatory diseases and metabolic disorders. In this context, the modulation of IFN-pathways by anti-IFNAR and antiJAK/STAT strategies gave promising results in vitro and might give some clues for future antiinflammatory strategies. Distinct combinations of anti-viral and immune-modulatory agents are already being tested. For example, the association of IFN $\alpha$ with IL-21 in cART-treated macaques during the chronic phase could potentially have a positive impact on both mucosal inflammation and viral reservoir [133]. Altogether, IFN-I has not spoken its last word and future studies are needed, 
based on previous lessons and recent innovations to test the potential benefit of IFN-I, in combination with other molecules, for controlling HIV in the context of HIV cure research. 


\section{REFERENCES}

[1] F. Barré-Sinoussi, A.L. Ross, J.-F. Delfraissy, Past, present and future: 30 years of HIV research, Nat. Rev. Microbiol. 11 (2013) 877-883. doi:10.1038/nrmicro3132.

[2] International AIDS Society Scientific Working Group on HIV Cure, S.G. Deeks, B. Autran, B. Berkhout, M. Benkirane, S. Cairns, N. Chomont, T.-W. Chun, M. Churchill, M. Di Mascio, C. Katlama, A. Lafeuillade, A. Landay, M. Lederman, S.R. Lewin, F. Maldarelli, D. Margolis, M. Markowitz, J. Martinez-Picado, J.I. Mullins, J. Mellors, S. Moreno, U. O’Doherty, S. Palmer, M.-C. Penicaud, M. Peterlin, G. Poli, J.-P. Routy, C. Rouzioux, G. Silvestri, M. Stevenson, A. Telenti, C. Van Lint, E. Verdin, A. Woolfrey, J. Zaia, F. Barré-Sinoussi, Towards an HIV cure: a global scientific strategy, Nat. Rev. Immunol. 12 (2012) 607-614. doi:10.1038/nri3262.

[3] J.D. Siliciano, R.F. Siliciano, Recent developments in the effort to cure HIV infection: going beyond N = 1, J. Clin. Invest. 126 (2016) 409-414. doi:10.1172/JCl86047.

[4] G. Maartens, C. Celum, S.R. Lewin, HIV infection: epidemiology, pathogenesis, treatment, and prevention, Lancet. 384 (2014) 258-271. doi:10.1016/S0140-6736(14)601641.

[5] H.M. Delagrèverie, C. Delaugerre, S.R. Lewin, S.G. Deeks, J.Z. Li, Ongoing Clinical Trials of Human Immunodeficiency Virus Latency-Reversing and Immunomodulatory Agents, Open Forum Infect. Dis. 3 (2016) ofw189. doi:10.1093/ofid/ofw189.

[6] A. Isaacs, J. Lindenmann, Virus interference. I. The interferon, Proc. R. Soc. Lond. B Biol. Sci. 147 (1957) 258-267.

[7] M.R. Capobianchi, E. Uleri, C. Caglioti, A. Dolei, Type I IFN family members: similarity, differences and interaction, Cytokine Growth Factor Rev. 26 (2015) 103-111. doi:10.1016/j.cytogfr.2014.10.011.

[8] J.I. Gallin, J.M. Farber, S.M. Holland, T.B. Nutman, Interferon-gamma in the management of infectious diseases, Ann. Intern. Med. 123 (1995) 216-224.

[9] S.V. Kotenko, G. Gallagher, V.V. Baurin, A. Lewis-Antes, M. Shen, N.K. Shah, J.A. Langer, F. Sheikh, H. Dickensheets, R.P. Donnelly, IFN-lambdas mediate antiviral protection through a distinct class II cytokine receptor complex, Nat. Immunol. 4 (2003) 69-77. doi:10.1038/ni875.

[10] P. Sheppard, W. Kindsvogel, W. Xu, K. Henderson, S. Schlutsmeyer, T.E. Whitmore, R. Kuestner, U. Garrigues, C. Birks, J. Roraback, C. Ostrander, D. Dong, J. Shin, S. Presnell, B. Fox, B. Haldeman, E. Cooper, D. Taft, T. Gilbert, F.J. Grant, M. Tackett, W. Krivan, G. McKnight, C. Clegg, D. Foster, K.M. Klucher, IL-28, IL-29 and their class II cytokine receptor IL28R, Nat. Immunol. 4 (2003) 63-68. doi:10.1038/ni873.

[11] E.A. Hemann, M. Gale, R. Savan, Interferon Lambda Genetics and Biology in Regulation of Viral Control, Front. Immunol. 8 (2017) 1707. doi:10.3389/fimmu.2017.01707. 
[12] T. Doyle, C. Goujon, M.H. Malim, HIV-1 and interferons: who's interfering with whom?, Nat. Rev. Microbiol. 13 (2015) 403-413. doi:10.1038/nrmicro3449.

[13] W.M. Schneider, M.D. Chevillotte, C.M. Rice, Interferon-stimulated genes: a complex web of host defenses, Annu. Rev. Immunol. 32 (2014) 513-545. doi:10.1146/annurevimmunol-032713-120231.

[14] A. Murira, A. Lamarre, Type-I Interferon Responses: From Friend to Foe in the Battle against Chronic Viral Infection, Front. Immunol. 7 (2016) 609.

doi:10.3389/fimmu.2016.00609.

[15] M.J. de Veer, M. Holko, M. Frevel, E. Walker, S. Der, J.M. Paranjape, R.H. Silverman, B.R. Williams, Functional classification of interferon-stimulated genes identified using microarrays, J. Leukoc. Biol. 69 (2001) 912-920.

[16] O. Falade-Nwulia, C. Suarez-Cuervo, D.R. Nelson, M.W. Fried, J.B. Segal, M.S. Sulkowski, Oral Direct-Acting Agent Therapy for Hepatitis C Virus Infection: A Systematic Review, Ann. Intern. Med. 166 (2017) 637-648. doi:10.7326/M16-2575.

[17] D.S. Reich, C.F. Lucchinetti, P.A. Calabresi, Multiple Sclerosis, N. Engl. J. Med. 378 (2018) 169-180. doi:10.1056/NEJMra1401483.

[18] T.S. Sandstrom, N. Ranganath, J.B. Angel, Impairment of the type I interferon response by HIV-1: Potential targets for HIV eradication, Cytokine Growth Factor Rev. 37 (2017) 1-16. doi:10.1016/j.cytogfr.2017.04.004.

[19] R. de Wit, J.K. Schattenkerk, C.A. Boucher, P.J. Bakker, K.H. Veenhof, S.A. Danner, Clinical and virological effects of high-dose recombinant interferon-alpha in disseminated AIDS-related Kaposi's sarcoma, Lancet Lond. Engl. 2 (1988) 1214-1217.

[20] H.C. Lane, J.A. Kovacs, J. Feinberg, B. Herpin, V. Davey, R. Walker, L. Deyton, J.A. Metcalf, M. Baseler, N. Salzman, Anti-retroviral effects of interferon-alpha in AIDS-associated Kaposi's sarcoma, Lancet Lond. Engl. 2 (1988) 1218-1222.

[21] H.C. Lane, V. Davey, J.A. Kovacs, J. Feinberg, J.A. Metcalf, B. Herpin, R. Walker, L. Deyton, R.T. Davey, J. Falloon, Interferon-alpha in patients with asymptomatic human immunodeficiency virus (HIV) infection. A randomized, placebo-controlled trial, Ann. Intern. Med. 112 (1990) 805-811.

[22] J. Rivero, M. Limonta, A. Aguilera, M. Fraga, P. López Saura, Use of recombinant interferon-alpha in human immunodeficiency virus (HIV)-infected individuals, Biotherapy Dordr. Neth. 8 (1994) 23-31.

[23] J. Rivero, M. Fraga, I. Cancio, J. Cuervo, P. López-Saura, Long-term treatment with recombinant interferon alpha-2b prolongs survival of asymptomatic HIV-infected individuals, Biotherapy Dordr. Neth. 10 (1997) 107-113.

[24] D.R. Skillman, J.L. Malone, C.F. Decker, K.F. Wagner, R.L. Mapou, M.J. Liao, D. Testa, M.S. Meltzer, Phase I trial of interferon alfa-n3 in early-stage human immunodeficiency virus type 1 disease: evidence for drug safety, tolerance, and antiviral activity, J. Infect. Dis. 173 
(1996) 1107-1114.

[25] G.J. Williams, C.B. Colby, Recombinant human interferon-beta suppresses the replication of HIV and acts synergistically with AZT, J. Interferon Res. 9 (1989) 709-718.

[26] B. Michaelis, J.A. Levy, HIV replication can be blocked by recombinant human interferon beta, AIDS Lond. Engl. 3 (1989) 27-31.

[27] S. Oka, Y. Hirabayashi, H. Mouri, S. Sakurada, H. Goto, K. Ohnishi, S. Kimura, K. Mitamura, K. Shimada, Beta-interferon and early stage HIV infection, J. Acquir. Immune Defic. Syndr. 2 (1989) 125-128.

[28] S.A. Miles, H.J. Wang, E. Cortes, J. Carden, S. Marcus, R.T. Mitsuyasu, Beta-interferon therapy in patients with poor-prognosis Kaposi sarcoma related to the acquired immunodeficiency syndrome (AIDS). A phase II trial with preliminary evidence of antiviral activity and low incidence of opportunistic infections, Ann. Intern. Med. 112 (1990) 582-589.

[29] R.L. Krigel, K.A. Padavic-Shaller, A.R. Rudolph, B.J. Poiesz, R.L. Comis, Exacerbation of epidemic Kaposi's sarcoma with a combination of interleukin-2 and beta-interferon: results of a phase 2 study, J. Biol. Response Mod. 8 (1989) 359-365.

[30] S. Miles, A. Levine, M. Feldstein, J. Carden, S. Cabriallas, S. Marcus, R. Mitsuyasu, P. Gill, Open-label phase I study of combination therapy with zidovudine and interferon-beta in patients with AIDS-related Kaposi's sarcoma: AIDS Clinical Trials Group Protocol 057, Cytokines Cell. Mol. Ther. 4 (1998) 17-23.

[31] W.M. El-Sadr, J.D. Lundgren, J.D. Neaton, F. Gordin, D. Abrams, R.C. Arduino, A. Babiker, W. Burman, N. Clumeck, C.J. Cohen, D. Cohn, D. Cooper, J. Darbyshire, S. Emery, G. Fätkenheuer, B. Gazzard, B. Grund, J. Hoy, K. Klingman, M. Losso, N. Markowitz, J. Neuhaus, A. Phillips, C. Rappoport, CD4+ count-guided interruption of antiretroviral treatment, N. Engl. J. Med. 355 (2006) 2283-2296. doi:10.1056/NEJMoa062360.

[32] T.W. Chun, D. Engel, S.B. Mizell, L.A. Ehler, A.S. Fauci, Induction of HIV-1 replication in latently infected CD4+ T cells using a combination of cytokines, J. Exp. Med. 188 (1998) 8391.

[33] J.D. Siliciano, R.F. Siliciano, Recent developments in the search for a cure for HIV-1 infection: targeting the latent reservoir for HIV-1, J. Allergy Clin. Immunol. 134 (2014) 12-19. doi:10.1016/j.jaci.2014.05.026.

[34] M.W. Fried, M.L. Shiffman, K.R. Reddy, C. Smith, G. Marinos, F.L. Gonçales, D. Häussinger, M. Diago, G. Carosi, D. Dhumeaux, A. Craxi, A. Lin, J. Hoffman, J. Yu, Peginterferon alfa-2a plus ribavirin for chronic hepatitis $C$ virus infection, N. Engl. J. Med. 347 (2002) 975-982. doi:10.1056/NEJMoa020047.

[35] H.L.-Y. Chan, N.W.-Y. Leung, A.Y. Hui, V.W.-S. Wong, C.-T. Liew, A.M.-L. Chim, F.K.-L. Chan, L.C.-T. Hung, Y.-T. Lee, J.S.-L. Tam, C.W.-K. Lam, J.J.-Y. Sung, A randomized, controlled trial of combination therapy for chronic hepatitis $\mathrm{B}$ : comparing pegylated interferon-alpha $2 \mathrm{~b}$ and lamivudine with lamivudine alone, Ann. Intern. Med. 142 (2005) 240-250. 
[36] D.M. Asmuth, R.L. Murphy, S.L. Rosenkranz, J.J.L. Lertora, S. Kottilil, Y. Cramer, E.S. Chan, R.T. Schooley, C.R. Rinaldo, N. Thielman, X.-D. Li, S.M. Wahl, J. Shore, J. Janik, R.A. Lempicki, Y. Simpson, R.B. Pollard, AIDS Clinical Trials Group A5192 Team, Safety, tolerability, and mechanisms of antiretroviral activity of pegylated interferon Alfa-2a in HIV-1-

monoinfected participants: a phase II clinical trial, J. Infect. Dis. 201 (2010) 1686-1696. doi:10.1086/652420.

[37] S.S. Iyer, F. Bibollet-Ruche, S. Sherrill-Mix, G.H. Learn, L. Plenderleith, A.G. Smith, H.J. Barbian, R.M. Russell, M.V.P. Gondim, C.Y. Bahari, C.M. Shaw, Y. Li, T. Decker, B.F. Haynes, G.M. Shaw, P.M. Sharp, P. Borrow, B.H. Hahn, Resistance to type 1 interferons is a major determinant of HIV-1 transmission fitness, Proc. Natl. Acad. Sci. U. S. A. 114 (2017) E590E599. doi:10.1073/pnas.1620144114.

[38] F. Dianzani, G. Rozera, I. Abbate, G. D’Offizi, A. Abdeddaim, C. Vlassi, G. Antonucci, P. Narciso, F. Martini, M.R. Capobianchi, Interferon may prevent HIV viral rebound after HAART interruption in HIV patients, J. Interferon Cytokine Res. Off. J. Int. Soc. Interferon Cytokine Res. 28 (2008) 1-3. doi:10.1089/jir.2007.0076.

[39] F. Boué, J. Reynes, C. Rouzioux, D. Emilie, F. Souala, R. Tubiana, C. Goujard, R. Lancar, D. Costagliola, Alpha interferon administration during structured interruptions of combination antiretroviral therapy in patients with chronic HIV-1 infection: INTERVAC ANRS 105 trial, AIDS Lond. Engl. 25 (2011) 115-118. doi:10.1097/QAD.0b013e328340a1e7.

[40] C. Goujard, D. Emilie, C. Roussillon, V. Godot, C. Rouzioux, A. Venet, C. Colin, G. Pialoux, P.-M. Girard, V. Boilet, M.-L. Chaix, P. Galanaud, G. Chene, ANRS-112 INTERPRIM Study Group, Continuous versus intermittent treatment strategies during primary HIV-1 infection: the randomized ANRS INTERPRIM Trial, AIDS Lond. Engl. 26 (2012) 1895-1905. doi:10.1097/QAD.0b013e32835844d9.

[41] L. Azzoni, A.S. Foulkes, E. Papasavvas, A.M. Mexas, K.M. Lynn, K. Mounzer, P. Tebas, J.M. Jacobson, I. Frank, M.P. Busch, S.G. Deeks, M. Carrington, U. O'Doherty, J. Kostman, L.J. Montaner, Pegylated Interferon alfa-2a monotherapy results in suppression of HIV type 1 replication and decreased cell-associated HIV DNA integration, J. Infect. Dis. 207 (2013) 213222. doi:10.1093/infdis/jis663.

[42] H. Sun, M.J. Buzon, A. Shaw, R.K. Berg, X.G. Yu, S. Ferrando-Martinez, M. Leal, E. RuizMateos, M. Lichterfeld, Hepatitis $C$ therapy with interferon- $\alpha$ and ribavirin reduces CD4 Tcell-associated HIV-1 DNA in HIV-1/hepatitis C virus-coinfected patients, J. Infect. Dis. 209 (2014) 1315-1320. doi:10.1093/infdis/jit628.

[43] Y. Jiao, W. Weng, Q. Gao, W. Zhu, W. Cai, L. Li, H. Li, Y. Gao, H. Wu, Hepatitis C therapy with interferon- $\alpha$ and ribavirin reduces the CD4 cell count and the total, 2LTR circular and integrated HIV-1 DNA in HIV/HCV co-infected patients, Antiviral Res. 118 (2015) 118-122. doi:10.1016/j.antiviral.2015.03.011.

[44] N. Huot, P. Rascle, T. Garcia-Tellez, B. Jacquelin, M. Müller-Trutwin, Innate immune cell responses in non pathogenic versus pathogenic SIV infections, Curr. Opin. Virol. 19 (2016) 37-44. doi:10.1016/j.coviro.2016.06.011. 
[45] T. Garcia-Tellez, N. Huot, M.J. Ploquin, P. Rascle, B. Jacquelin, M. Müller-Trutwin, Non-human primates in HIV research: Achievements, limits and alternatives, Infect. Genet. Evol. J. Mol. Epidemiol. Evol. Genet. Infect. Dis. 46 (2016) 324-332. doi:10.1016/j.meegid.2016.07.012.

[46] S.E. Bosinger, Q. Li, S.N. Gordon, N.R. Klatt, L. Duan, L. Xu, N. Francella, A. Sidahmed, A.J. Smith, E.M. Cramer, M. Zeng, D. Masopust, J.V. Carlis, L. Ran, T.H. Vanderford, M. Paiardini, R.B. Isett, D.A. Baldwin, J.G. Else, S.I. Staprans, G. Silvestri, A.T. Haase, D.J. Kelvin, Global genomic analysis reveals rapid control of a robust innate response in SIV-infected sooty mangabeys, J. Clin. Invest. 119 (2009) 3556-3572. doi:10.1172/JCl40115.

[47] B. Jacquelin, V. Mayau, B. Targat, A.-S. Liovat, D. Kunkel, G. Petitjean, M.-A. Dillies, P. Roques, C. Butor, G. Silvestri, L.D. Giavedoni, P. Lebon, F. Barré-Sinoussi, A. Benecke, M.C. Müller-Trutwin, Nonpathogenic SIV infection of African green monkeys induces a strong but rapidly controlled type I IFN response, J. Clin. Invest. 119 (2009) 3544-3555.

doi:10.1172/JCl40093.

[48] L.D. Harris, B. Tabb, D.L. Sodora, M. Paiardini, N.R. Klatt, D.C. Douek, G. Silvestri, M. Müller-Trutwin, I. Vasile-Pandrea, C. Apetrei, V. Hirsch, J. Lifson, J.M. Brenchley, J.D. Estes, Downregulation of robust acute type I interferon responses distinguishes nonpathogenic simian immunodeficiency virus (SIV) infection of natural hosts from pathogenic SIV infection of rhesus macaques, J. Virol. 84 (2010) 7886-7891. doi:10.1128/JVI.02612-09.

[49] B. Jacquelin, G. Petitjean, D. Kunkel, A.-S. Liovat, S.P. Jochems, K.A. Rogers, M.J. Ploquin, Y. Madec, F. Barré-Sinoussi, N. Dereuddre-Bosquet, P. Lebon, R. Le Grand, F. Villinger, M. Müller-Trutwin, Innate immune responses and rapid control of inflammation in African green monkeys treated or not with interferon-alpha during primary SIVagm infection, PLoS Pathog. 10 (2014) e1004241. doi:10.1371/journal.ppat.1004241.

[50] T.H. Vanderford, C. Slichter, K.A. Rogers, B.O. Lawson, R. Obaede, J. Else, F. Villinger, S.E. Bosinger, G. Silvestri, Treatment of SIV-infected sooty mangabeys with a type-I IFN agonist results in decreased virus replication without inducing hyperimmune activation, Blood. 119 (2012) 5750-5757. doi:10.1182/blood-2012-02-411496.

[51] N.G. Sandler, S.E. Bosinger, J.D. Estes, R.T.R. Zhu, G.K. Tharp, E. Boritz, D. Levin, S. Wijeyesinghe, K.N. Makamdop, G.Q. del Prete, B.J. Hill, J.K. Timmer, E. Reiss, G. Yarden, S. Darko, E. Contijoch, J.P. Todd, G. Silvestri, M. Nason, R.B. Norgren, B.F. Keele, S. Rao, J.A. Langer, J.D. Lifson, G. Schreiber, D.C. Douek, Type I interferon responses in rhesus macaques prevent SIV infection and slow disease progression, Nature. 511 (2014) 601-605. doi:10.1038/nature13554.

[52] S. Fernandez, S. Tanaskovic, K. Helbig, R. Rajasuriar, M. Kramski, J.M. Murray, M. Beard, D. Purcell, S.R. Lewin, P. Price, M.A. French, CD4+ T-cell deficiency in HIV patients responding to antiretroviral therapy is associated with increased expression of interferonstimulated genes in CD4+ T cells, J. Infect. Dis. 204 (2011) 1927-1935. doi:10.1093/infdis/jir659.

[53] G.A.D. Hardy, S. Sieg, B. Rodriguez, D. Anthony, R. Asaad, W. Jiang, J. Mudd, T. 
Schacker, N.T. Funderburg, H.A. Pilch-Cooper, R. Debernardo, R.L. Rabin, M.M. Lederman, C.V. Harding, Interferon- $\alpha$ is the primary plasma type-I IFN in HIV-1 infection and correlates with immune activation and disease markers, PloS One. 8 (2013) e56527. doi:10.1371/journal.pone.0056527.

[54] N. Noel, F. Boufassa, C. Lécuroux, A. Saez-Cirion, C. Bourgeois, C. Dunyach-Remy, C. Goujard, C. Rouzioux, L. Meyer, G. Pancino, A. Venet, O. Lambotte, ANRS C021 CODEX Study Group, Elevated IP10 levels are associated with immune activation and low $\mathrm{CD}^{+}{ }^{+} \mathrm{T}$-cell counts in HIV controller patients, AIDS Lond. Engl. 28 (2014) 467-476. doi:10.1097/QAD.0000000000000174.

[55] M.J. Ploquin, Y. Madec, A. Casrouge, N. Huot, C. Passaes, C. Lécuroux, A. Essat, F. Boufassa, B. Jacquelin, S.P. Jochems, G. Petitjean, M. Angin, K. Gärtner, T. Garcia-Tellez, N. Noël, T. Booiman, B.D. Boeser-Nunnink, P. Roques, A. Saez-Cirion, B. Vaslin, N. DereudreBosquet, F. Barré-Sinoussi, M. Ghislain, C. Rouzioux, O. Lambotte, M.L. Albert, C. Goujard, N. Kootstra, L. Meyer, M.C. Müller-Trutwin, Elevated Basal Pre-infection CXCL10 in Plasma and in the Small Intestine after Infection Are Associated with More Rapid HIV/SIV Disease Onset, PLoS Pathog. 12 (2016) e1005774. doi:10.1371/journal.ppat.1005774.

[56] E. Canoui, N. Noël, C. Lécuroux, F. Boufassa, A. Sáez-Cirión, C. Bourgeois, O. Lambotte, ANRS CO21 CODEX Study Group, Strong ifitm1 Expression in CD4 T Cells in HIV Controllers Is Correlated With Immune Activation, J. Acquir. Immune Defic. Syndr. 1999. 74 (2017) e56-e59. doi:10.1097/QAI.0000000000001166.

[57] C. Lehmann, M. Lafferty, A. Garzino-Demo, N. Jung, P. Hartmann, G. Fätkenheuer, J.S. Wolf, J. van Lunzen, F. Romerio, Plasmacytoid dendritic cells accumulate and secrete interferon alpha in lymph nodes of HIV-1 patients, PloS One. 5 (2010) e11110. doi:10.1371/journal.pone.0011110.

[58] M. Paiardini, M. Müller-Trutwin, HIV-associated chronic immune activation, Immunol. Rev. 254 (2013) 78-101. doi:10.1111/imr.12079.

[59] G.A.D. Hardy, S.F. Sieg, B. Rodriguez, W. Jiang, R. Asaad, M.M. Lederman, C.V. Harding, Desensitization to type I interferon in HIV-1 infection correlates with markers of immune activation and disease progression, Blood. 113 (2009) 5497-5505. doi:10.1182/blood-2008-11-190231.

[60] A. Yadav, P. Fitzgerald, M.M. Sajadi, B. Gilliam, M.K. Lafferty, R. Redfield, W. Reid, Increased expression of suppressor of cytokine signaling-1 (SOCS-1): A mechanism for dysregulated T helper-1 responses in HIV-1 disease, Virology. 385 (2009) 126-133. doi:10.1016/j.virol.2008.11.039.

[61] L.N. Akhtar, H. Qin, M.T. Muldowney, L.L. Yanagisawa, O. Kutsch, J.E. Clements, E.N. Benveniste, Suppressor of cytokine signaling 3 inhibits antiviral IFN-beta signaling to enhance HIV-1 replication in macrophages, J. Immunol. Baltim. Md 1950. 185 (2010) 2393-2404. doi:10.4049/jimmunol.0903563.

[62] N. Ranganath, T.S. Sandstrom, S. Fadel, S.C. Côté, J.B. Angel, Type I interferon 
responses are impaired in latently HIV infected cells, Retrovirology. 13 (2016) 66. doi:10.1186/s12977-016-0302-9.

[63] M.P. Hardy, C.M. Owczarek, L.S. Jermiin, M. Ejdebäck, P.J. Hertzog, Characterization of the type I interferon locus and identification of novel genes, Genomics. 84 (2004) 331345. doi:10.1016/j.ygeno.2004.03.003.

[64] C. Thomas, I. Moraga, D. Levin, P.O. Krutzik, Y. Podoplelova, A. Trejo, C. Lee, G. Yarden, S.E. Vleck, J.S. Glenn, G.P. Nolan, J. Piehler, G. Schreiber, K.C. Garcia, Structural linkage between ligand discrimination and receptor activation by type I interferons, Cell. 146 (2011) 621-632. doi:10.1016/j.cell.2011.06.048.

[65] E. Jaks, M. Gavutis, G. Uzé, J. Martal, J. Piehler, Differential receptor subunit affinities of type I interferons govern differential signal activation, J. Mol. Biol. 366 (2007) 525-539. doi:10.1016/j.jmb.2006.11.053.

[66] K. Gibbert, J.J. Joedicke, A. Meryk, M. Trilling, S. Francois, J. Duppach, A. Kraft, K.S. Lang, U. Dittmer, Interferon-alpha subtype 11 activates NK cells and enables control of retroviral infection, PLoS Pathog. 8 (2012) e1002868. doi:10.1371/journal.ppat.1002868.

[67] W.S. Yeow, C.M. Lai, M.W. Beilharz, The in vivo expression patterns of individual type I interferon genes in murine cytomegalovirus infections, Antiviral Res. 34 (1997) 17-26.

[68] N. Gerlach, K. Gibbert, C. Alter, S. Nair, G. Zelinskyy, C.M. James, U. Dittmer, Antiretroviral effects of type I IFN subtypes in vivo, Eur. J. Immunol. 39 (2009) 136-146. doi:10.1002/eji.200838311.

[69] M.S. Harper, K. Guo, K. Gibbert, E.J. Lee, S.M. Dillon, B.S. Barrett, M.D. McCarter, K.J. Hasenkrug, U. Dittmer, C.C. Wilson, M.L. Santiago, Interferon- $\alpha$ Subtypes in an Ex Vivo Model of Acute HIV-1 Infection: Expression, Potency and Effector Mechanisms, PLoS Pathog. 11 (2015) e1005254. doi:10.1371/journal.ppat.1005254.

[70] K.J. Lavender, K. Gibbert, K.E. Peterson, E. Van Dis, S. Francois, T. Woods, R.J. Messer, A. Gawanbacht, J.A. Müller, J. Münch, K. Phillips, B. Race, M.S. Harper, K. Guo, E.J. Lee, M. Trilling, H. Hengel, J. Piehler, J. Verheyen, C.C. Wilson, M.L. Santiago, K.J. Hasenkrug, U. Dittmer, Interferon Alpha Subtype-Specific Suppression of HIV-1 Infection In Vivo, J. Virol. 90 (2016) 6001-6013. doi:10.1128/JVI.00451-16.

[71] S. Abraham, J.-G. Choi, N.M. Ortega, J. Zhang, P. Shankar, N.M. Swamy, Gene therapy with plasmids encoding IFN- $\beta$ or IFN- $\alpha 14$ confers long-term resistance to HIV- 1 in humanized mice, Oncotarget. 7 (2016) 78412-78420. doi:10.18632/oncotarget.12512.

[72] K. Abel, M.J. Alegria-Hartman, K. Rothaeusler, M. Marthas, C.J. Miller, The relationship between simian immunodeficiency virus RNA levels and the mRNA levels of alpha/beta interferons (IFN-alpha/beta) and IFN-alpha/beta-inducible Mx in lymphoid tissues of rhesus macaques during acute and chronic infection, J. Virol. 76 (2002) 8433-8445.

[73] C. Lehmann, D. Taubert, N. Jung, G. Fätkenheuer, J. van Lunzen, P. Hartmann, F. Romerio, Preferential upregulation of interferon-alpha subtype 2 expression in HIV-1 
patients, AIDS Res. Hum. Retroviruses. 25 (2009) 577-581. doi:10.1089/aid.2008.0238.

[74] J. Dutrieux, V. Fabre-Mersseman, B. Charmeteau-De Muylder, M. Rancez, R. Ponte, S. Rozlan, S. Figueiredo-Morgado, A. Bernard, S. Beq, A. Couëdel-Courteille, R. Cheynier, Modified interferon- $\alpha$ subtypes production and chemokine networks in the thymus during acute simian immunodeficiency virus infection, impact on thymopoiesis, AIDS Lond. Engl. 28 (2014) 1101-1113. doi:10.1097/QAD.0000000000000249.

[75] Y. Li, B. Sun, S. Esser, H. Jessen, H. Streeck, M. Widera, R. Yang, U. Dittmer, K. Sutter, Expression Pattern of Individual IFNA Subtypes in Chronic HIV Infection, J. Interferon Cytokine Res. Off. J. Int. Soc. Interferon Cytokine Res. 37 (2017) 541-549. doi:10.1089/jir.2017.0076.

[76] M.P. Rodero, J. Decalf, V. Bondet, D. Hunt, G.I. Rice, S. Werneke, S.L. McGlasson, M.A. Alyanakian, B. Bader-Meunier, C. Barnerias, N. Bellon, A. Belot, C. Bodemer, T.A. Briggs, I. Desguerre, M.-L. Frémond, M. Hully, A.M.J.M. van den Maagdenberg, I. Melki, I. Meyts, L. Musset, N. Pelzer, P. Quartier, G.M. Terwindt, J. Wardlaw, S. Wiseman, F. Rieux-Laucat, Y. Rose, B. Neven, C. Hertel, A. Hayday, M.L. Albert, F. Rozenberg, Y.J. Crow, D. Duffy, Detection of interferon alpha protein reveals differential levels and cellular sources in disease, J. Exp. Med. 214 (2017) 1547-1555. doi:10.1084/jem.20161451.

[77] R.S. Veazey, H.A. Pilch-Cooper, T.J. Hope, G. Alter, A.M. Carias, M. Sips, X. Wang, B. Rodriguez, S.F. Sieg, A. Reich, P. Wilkinson, M.J. Cameron, M.M. Lederman, Prevention of SHIV transmission by topical IFN- $\beta$ treatment, Mucosal Immunol. 9 (2016) 1528-1536. doi:10.1038/mi.2015.146.

[78] Y. Wang, K. Abel, K. Lantz, A.M. Krieg, M.B. McChesney, C.J. Miller, The Toll-like receptor 7 (TLR7) agonist, imiquimod, and the TLR9 agonist, CpG ODN, induce antiviral cytokines and chemokines but do not prevent vaginal transmission of simian immunodeficiency virus when applied intravaginally to rhesus macaques, J. Virol. 79 (2005) 14355-14370. doi:10.1128/JVI.79.22.14355-14370.2005.

[79] K.Y. Fung, N.E. Mangan, H. Cumming, J.C. Horvat, J.R. Mayall, S.A. Stifter, N. De Weerd, L.C. Roisman, J. Rossjohn, S.A. Robertson, J.E. Schjenken, B. Parker, C.E. Gargett, H.P.T. Nguyen, D.J. Carr, P.M. Hansbro, P.J. Hertzog, Interferon- $\varepsilon$ protects the female reproductive tract from viral and bacterial infection, Science. 339 (2013) 1088-1092. doi:10.1126/science.1233321.

[80] S.A. Stifter, A.Y. Matthews, N.E. Mangan, K.Y. Fung, A. Drew, M.D. Tate, T.P. Soares da Costa, D. Hampsey, J. Mayall, P.M. Hansbro, A. Garcia Minambres, S.G. Eid, J. Mak, J. Scoble, G. Lovrecz, N.A. de Weerd, P.J. Hertzog, Defining the distinct, intrinsic properties of the novel type I interferon, epsilon, J. Biol. Chem. (2017). doi:10.1074/jbc.M117.800755.

[81] A. Garcia-Minambres, S.G. Eid, N.E. Mangan, C. Pade, S.S. Lim, A.Y. Matthews, N.A. de Weerd, P.J. Hertzog, J. Mak, Interferon epsilon promotes HIV restriction at multiple steps of viral replication, Immunol. Cell Biol. 95 (2017) 478-483. doi:10.1038/icb.2016.123.

[82] C. Tasker, S. Subbian, P. Gao, J. Couret, C. Levine, S. Ghanny, P. Soteropoulos, X. Zhao, 
N. Landau, W. Lu, T.L. Chang, IFN-eprotects primary macrophages against HIV infection, JCI Insight. 1 (2016) e88255. doi:10.1172/jci.insight.88255.

[83] J. Pott, T. Mahlakõiv, M. Mordstein, C.U. Duerr, T. Michiels, S. Stockinger, P. Staeheli, M.W. Hornef, IFN-lambda determines the intestinal epithelial antiviral host defense, Proc. Natl. Acad. Sci. U. S. A. 108 (2011) 7944-7949. doi:10.1073/pnas.1100552108.

[84] M.T. Baldridge, S. Lee, J.J. Brown, N. McAllister, K. Urbanek, T.S. Dermody, T.J. Nice, H.W. Virgin, Expression ofIfnlr1on Intestinal Epithelial Cells Is Critical to the Antiviral Effects of Interferon Lambda against Norovirus and Reovirus, J. Virol. 91 (2017).

doi:10.1128/JVI.02079-16.

[85] H.M. Lazear, T.J. Nice, M.S. Diamond, Interferon- $\lambda$ : Immune Functions at Barrier Surfaces and Beyond, Immunity. 43 (2015) 15-28. doi:10.1016/j.immuni.2015.07.001.

[86] W. Hou, X. Wang, L. Ye, L. Zhou, Z.-Q. Yang, E. Riedel, W.-Z. Ho, Lambda interferon inhibits human immunodeficiency virus type 1 infection of macrophages, J. Virol. 83 (2009) 3834-3842. doi:10.1128/JVI.01773-08.

[87] M.-Q. Liu, D.-J. Zhou, X. Wang, W. Zhou, L. Ye, J.-L. Li, Y.-Z. Wang, W.-Z. Ho, IFN- $\lambda 3$ inhibits HIV infection of macrophages through the JAK-STAT pathway, PloS One. 7 (2012) e35902. doi:10.1371/journal.pone.0035902.

[88] Y. Wang, J. Li, X. Wang, Y. Zhou, T. Zhang, W. Ho, Comparison of antiviral activity of lambda-interferons against HIV replication in macrophages, J. Interferon Cytokine Res. Off. J. Int. Soc. Interferon Cytokine Res. 35 (2015) 213-221. doi:10.1089/jir.2014.0064.

[89] R.-R. Tian, H.-X. Guo, J.-F. Wei, C.-K. Yang, S.-H. He, J.-H. Wang, IFN- $\lambda$ inhibits HIV-1 integration and post-transcriptional events in vitro, but there is only limited in vivo repression of viral production, Antiviral Res. 95 (2012) 57-65.

doi:10.1016/j.antiviral.2012.04.011.

[90] J. Li, Y. Wang, X. Wang, L. Ye, Y. Zhou, Y. Persidsky, W. Ho, Immune activation of human brain microvascular endothelial cells inhibits HIV replication in macrophages, Blood. 121 (2013) 2934-2942. doi:10.1182/blood-2012-08-450353.

[91] X. Wang, H. Wang, M.-Q. Liu, J.-L. Li, R.-H. Zhou, Y. Zhou, Y.-Z. Wang, W. Zhou, W.-Z. Ho, IFN- $\lambda$ Inhibits Drug-Resistant HIV Infection of Macrophages, Front. Immunol. 8 (2017) 210. doi:10.3389/fimmu.2017.00210.

[92] S. Phillips, S. Mistry, A. Riva, H. Cooksley, T. Hadzhiolova-Lebeau, S. Plavova, K. Katzarov, M. Simonova, S. Zeuzem, C. Woffendin, P.-J. Chen, C.-Y. Peng, T.-T. Chang, S. Lueth, R. De Knegt, M.-S. Choi, H. Wedemeyer, M. Dao, C.-W. Kim, H.-C. Chu, M. Wind-Rotolo, R. Williams, E. Cooney, S. Chokshi, Peg-Interferon Lambda Treatment Induces Robust Innate and Adaptive Immunity in Chronic Hepatitis B Patients, Front. Immunol. 8 (2017) 621. doi:10.3389/fimmu.2017.00621.

[93] J. Friborg, S. Levine, C. Chen, A.K. Sheaffer, S. Chaniewski, S. Voss, J.A. Lemm, F. McPhee, Combinations of lambda interferon with direct-acting antiviral agents are highly 
efficient in suppressing hepatitis C virus replication, Antimicrob. Agents Chemother. 57 (2013) 1312-1322. doi:10.1128/AAC.02239-12.

[94] M. Nelson, R. Rubio, A. Lazzarin, S. Romanova, A. Luetkemeyer, B. Conway, J.-M. Molina, D. Xu, S. Srinivasan, S. Portsmouth, Safety and Efficacy of Pegylated Interferon Lambda, Ribavirin, and Daclatasvir in HCV and HIV-Coinfected Patients, J. Interferon Cytokine Res. Off. J. Int. Soc. Interferon Cytokine Res. 37 (2017) 103-111. doi:10.1089/jir.2016.0082.

[95] R.J. Gilson, J.L. Shupack, A.E. Friedman-Kien, M.A. Conant, J.N. Weber, A.T. Nayagam, R.V. Swann, D.C. Pietig, M.H. Smith, M.L. Owens, A randomized, controlled, safety study using imiquimod for the topical treatment of anogenital warts in HIV-infected patients. Imiquimod Study Group, AIDS Lond. Engl. 13 (1999) 2397-2404.

[96] P.A. Fox, M. Nathan, N. Francis, N. Singh, J. Weir, G. Dixon, S.E. Barton, M. Bower, A double-blind, randomized controlled trial of the use of imiquimod cream for the treatment of anal canal high-grade anal intraepithelial neoplasia in HIV-positive MSM on HAART, with long-term follow-up data including the use of open-label imiquimod, AIDS Lond. Engl. 24 (2010) 2331-2335. doi:10.1097/QAD.0b013e32833d466c.

[97] H. Hofmann, B. Vanwalscappel, N. Bloch, N.R. Landau, TLR7/8 agonist induces a postentry SAMHD1-independent block to HIV-1 infection of monocytes, Retrovirology. 13 (2016) 83. doi:10.1186/s12977-016-0316-3.

[98] P.F. McKay, D.F.L. King, J.F.S. Mann, G. Barinaga, D. Carter, R.J. Shattock, TLR4 and TLR7/8 Adjuvant Combinations Generate Different Vaccine Antigen-Specific Immune Outcomes in Minipigs when Administered via the ID or IN Routes, PloS One. 11 (2016) e0148984. doi:10.1371/journal.pone.0148984.

[99] E. Poteet, P. Lewis, C. Chen, S.O. Ho, T. Do, S. Chiang, C. Labranche, D. Montefiori, G. Fujii, Q. Yao, Toll-like receptor 3 adjuvant in combination with virus-like particles elicit a humoral response against HIV, Vaccine. 34 (2016) 5886-5894.

doi:10.1016/j.vaccine.2016.10.036.

[100] I. Rebbapragada, G. Birkus, J. Perry, W. Xing, H. Kwon, S. Pflanz, Molecular Determinants of GS-9620-Dependent TLR7 Activation, PloS One. 11 (2016) e0146835. doi:10.1371/journal.pone.0146835.

[101] R.A. Bam, D. Hansen, A. Irrinki, A. Mulato, G.S. Jones, J. Hesselgesser, C.R. Frey, T. Cihlar, S.R. Yant, TLR7 Agonist GS-9620 Is a Potent Inhibitor of Acute HIV-1 Infection in Human Peripheral Blood Mononuclear Cells, Antimicrob. Agents Chemother. 61 (2017). doi:10.1128/AAC.01369-16.

[102] A. Tsai, A. Irrinki, J. Kaur, T. Cihlar, G. Kukolj, D.D. Sloan, J.P. Murry, Toll-Like Receptor 7 Agonist GS-9620 Induces HIV Expression and HIV-Specific Immunity in Cells from HIVInfected Individuals on Suppressive Antiretroviral Therapy, J. Virol. 91 (2017). doi:10.1128/JVI.02166-16.

[103] R. Offersen, S.K. Nissen, T.A. Rasmussen, L. Østergaard, P.W. Denton, O.S. Søgaard, M. Tolstrup, A Novel Toll-Like Receptor 9 Agonist, MGN1703, Enhances HIV-1 Transcription 
and NK Cell-Mediated Inhibition of HIV-1-Infected Autologous CD4+ T Cells, J. Virol. 90 (2016) 4441-4453. doi:10.1128/JVI.00222-16.

[104] L. Vibholm, M.H. Schleimann, J.F. Højen, T. Benfield, R. Offersen, K. Rasmussen, R. Olesen, A. Dige, J. Agnholt, J. Grau, M. Buzon, B. Wittig, M. Lichterfeld, A.M. Petersen, X. Deng, M. Abdel-Mohsen, S.K. Pillai, S. Rutsaert, W. Trypsteen, W. De Spiegelaere, L. Vandekerchove, L. Østergaard, T.A. Rasmussen, P.W. Denton, M. Tolstrup, O.S. Søgaard, Short-Course Toll-Like Receptor 9 Agonist Treatment Impacts Innate Immunity and Plasma Viremia in Individuals With Human Immunodeficiency Virus Infection, Clin. Infect. Dis. Off. Publ. Infect. Dis. Soc. Am. 64 (2017) 1686-1695. doi:10.1093/cid/cix201.

[105] A.R. Krarup, M. Abdel-Mohsen, M.H. Schleimann, L. Vibholm, P.A. Engen, A. Dige, B. Wittig, M. Schmidt, S.J. Green, A. Naqib, A. Keshavarzian, X. Deng, R. Olesen, A.M. Petersen, T. Benfield, L. Østergaard, T.A. Rasmussen, J. Agnholt, J.R. Nyengaard, A. Landay, O.S. Søgaard, S.K. Pillai, M. Tolstrup, P.W. Denton, The TLR9 agonist MGN1703 triggers a potent type I interferon response in the sigmoid colon, Mucosal Immunol. (2017). doi:10.1038/mi.2017.59.

[106] P.W. Hunt, J. Brenchley, E. Sinclair, J.M. McCune, M. Roland, K. Page-Shafer, P. Hsue, B. Emu, M. Krone, H. Lampiris, D. Douek, J.N. Martin, S.G. Deeks, Relationship between T cell activation and CD4+ T cell count in HIV-seropositive individuals with undetectable plasma HIV RNA levels in the absence of therapy, J. Infect. Dis. 197 (2008) 126-133. doi:10.1086/524143.

[107] D.R. Boulware, K.H. Hullsiek, C.E. Puronen, A. Rupert, J.V. Baker, M.A. French, P.R. Bohjanen, R.M. Novak, J.D. Neaton, I. Sereti, Higher levels of CRP, D-dimer, IL-6, and hyaluronic acid before initiation of antiretroviral therapy (ART) are associated with increased risk of AIDS or death, J. Infect. Dis. 203 (2011) 1637-1646. doi:10.1093/infdis/jir134.

[108] Á.H. Borges, M.J. Silverberg, D. Wentworth, A.E. Grulich, G. Fätkenheuer, R. Mitsuyasu, G. Tambussi, C.A. Sabin, J.D. Neaton, J.D. Lundgren, INSIGHT SMART, ESPRIT, SILCAAT Study Groups, Predicting risk of cancer during HIV infection: the role of inflammatory and coagulation biomarkers, AIDS Lond. Engl. 27 (2013) 1433-1441. doi:10.1097/QAD.0b013e32835f6b0c.

[109] A.D. Nordell, M. McKenna, Á.H. Borges, D. Duprez, J. Neuhaus, J.D. Neaton, INSIGHT SMART, ESPRIT Study Groups, SILCAAT Scientific Committee, Severity of cardiovascular disease outcomes among patients with HIV is related to markers of inflammation and coagulation, J. Am. Heart Assoc. 3 (2014) e000844. doi:10.1161/JAHA.114.000844.

[110] I. Sereti, S.J. Krebs, N. Phanuphak, J.L. Fletcher, B. Slike, S. Pinyakorn, R.J. O'Connell, A. Rupert, N. Chomont, V. Valcour, J.H. Kim, M.L. Robb, N.L. Michael, D.C. Douek, J. Ananworanich, N.S. Utay, RV254/SEARCH 010, RV304/SEARCH 013 and SEARCH 011 protocol teams, Persistent, Albeit Reduced, Chronic Inflammation in Persons Starting Antiretroviral Therapy in Acute HIV Infection, Clin. Infect. Dis. Off. Publ. Infect. Dis. Soc. Am. 64 (2017) 124-131. doi:10.1093/cid/ciw683.

[111] N. Noel, N. Lerolle, C. Lécuroux, C. Goujard, A. Venet, A. Saez-Cirion, V. Avettand- 
Fenoël, L. Meyer, F. Boufassa, O. Lambotte, ANRS C021 CODEX Study Group, Immunologic and Virologic Progression in HIV Controllers: The Role of Viral "Blips" and Immune Activation in the ANRS CO21 CODEX Study, PloS One. 10 (2015) e0131922.

doi:10.1371/journal.pone.0131922.

[112] E.H. Loughlin, J.B. Rice, H.S. Wells, I. Rappaport, A.A. Joseph, The treatment of Plasmodium falciparum malaria with a single dose antimalarial; a preliminary report of the use of hydroxychloroquine, 7-chloro-4(4-(N-ethyl-N-B-hydroxyethylamino)-1methylbutylamino)-quinoline diphosphate, Antibiot. Chemother. Northfield III. 2 (1952) 171174.

[113] N. Costedoat-Chalumeau, L. Galicier, O. Aumaître, C. Francès, V. Le Guern, F. Lioté, A. Smail, N. Limal, L. Perard, H. Desmurs-Clavel, D.L.T.H. Boutin, B. Asli, J.-E. Kahn, J. Pourrat, L. Sailler, F. Ackermann, T. Papo, K. Sacré, O. Fain, J. Stirnemann, P. Cacoub, M. Jallouli, G. Leroux, J. Cohen-Bittan, M.-L. Tanguy, J.-S. Hulot, P. Lechat, L. Musset, Z. Amoura, J.-C. Piette, Group PLUS, Hydroxychloroquine in systemic lupus erythematosus: results of a French multicentre controlled trial (PLUS Study), Ann. Rheum. Dis. 72 (2013) 1786-1792. doi:10.1136/annrheumdis-2012-202322.

[114] V. Ravindran, G. Alias, Efficacy of combination DMARD therapy vs. hydroxychloroquine monotherapy in chronic persistent chikungunya arthritis: a 24-week randomized controlled open label study, Clin. Rheumatol. 36 (2017) 1335-1340. doi:10.1007/s10067-016-3429-0.

[115] J.A. Martinson, C.J. Montoya, X. Usuga, R. Ronquillo, A.L. Landay, S.N. Desai, Chloroquine modulates HIV-1-induced plasmacytoid dendritic cell alpha interferon: implication for T-cell activation, Antimicrob. Agents Chemother. 54 (2010) 871-881. doi:10.1128/AAC.01246-09.

[116] S.M. Murray, C.M. Down, D.R. Boulware, W.M. Stauffer, W.P. Cavert, T.W. Schacker, J.M. Brenchley, D.C. Douek, Reduction of immune activation with chloroquine therapy during chronic HIV infection, J. Virol. 84 (2010) 12082-12086. doi:10.1128/JVI.01466-10.

[117] S. Piconi, S. Parisotto, G. Rizzardini, S. Passerini, R. Terzi, B. Argenteri, P. Meraviglia, A. Capetti, M. Biasin, D. Trabattoni, M. Clerici, Hydroxychloroquine drastically reduces immune activation in HIV-infected, antiretroviral therapy-treated immunologic nonresponders, Blood. 118 (2011) 3263-3272. doi:10.1182/blood-2011-01-329060.

[118] J.-P. Routy, J.B. Angel, M. Patel, C. Kanagaratham, D. Radzioch, I. Kema, N. Gilmore, P. Ancuta, J. Singer, M.-A. Jenabian, Assessment of chloroquine as a modulator of immune activation to improve CD4 recovery in immune nonresponding HIV-infected patients receiving antiretroviral therapy, HIV Med. 16 (2015) 48-56. doi:10.1111/hiv.12171.

[119] N.I. Paton, R.L. Goodall, D.T. Dunn, S. Franzen, Y. Collaco-Moraes, B.G. Gazzard, I.G. Williams, M.J. Fisher, A. Winston, J. Fox, C. Orkin, E.A. Herieka, J.G. Ainsworth, F.A. Post, M. Wansbrough-Jones, P. Kelleher, Hydroxychloroquine Trial Team, Effects of hydroxychloroquine on immune activation and disease progression among HIV-infected patients not receiving antiretroviral therapy: a randomized controlled trial, JAMA. 308 (2012) 
353-361. doi:10.1001/jama.2012.6936.

[120] A. Zhen, V. Rezek, C. Youn, B. Lam, N. Chang, J. Rick, M. Carrillo, H. Martin, S. Kasparian, P. Syed, N. Rice, D.G. Brooks, S.G. Kitchen, Targeting type I interferon-mediated activation restores immune function in chronic HIV infection, J. Clin. Invest. 127 (2017) 260268. doi:10.1172/JCl89488.

[121] L. Cheng, J. Ma, J. Li, D. Li, G. Li, F. Li, Q. Zhang, H. Yu, F. Yasui, C. Ye, L.-C. Tsao, Z. Hu, L. Su, L. Zhang, Blocking type I interferon signaling enhances T cell recovery and reduces HIV1 reservoirs, J. Clin. Invest. 127 (2017) 269-279. doi:10.1172/JCI90745.

[122] S.G. Deeks, P.M. Odorizzi, R.-P. Sekaly, The interferon paradox: can inhibiting an antiviral mechanism advance an HIV cure?, J. Clin. Invest. 127 (2017) 103-105.

doi:10.1172/JCI91916.

[123] R. Furie, M. Khamashta, J.T. Merrill, V.P. Werth, K. Kalunian, P. Brohawn, G.G. Illei, J. Drappa, L. Wang, S. Yoo, CD1013 Study Investigators, Anifrolumab, an Anti-Interferon- $\alpha$ Receptor Monoclonal Antibody, in Moderate-to-Severe Systemic Lupus Erythematosus, Arthritis Rheumatol. Hoboken NJ. 69 (2017) 376-386. doi:10.1002/art.39962.

[124] J.J. Kohler, D.L. Tuttle, C.R. Coberley, J.W. Sleasman, M.M. Goodenow, Human immunodeficiency virus type 1 (HIV-1) induces activation of multiple STATs in CD4+ cells of lymphocyte or monocyte/macrophage lineages, J. Leukoc. Biol. 73 (2003) 407-416.

[125] C. Bovolenta, L. Camorali, A.L. Lorini, S. Ghezzi, E. Vicenzi, A. Lazzarin, G. Poli, Constitutive activation of STATs upon in vivo human immunodeficiency virus infection, Blood. 94 (1999) 4202-4209.

[126] A. Alhetheel, Y. Yakubtsov, K. Abdkader, N. Sant, F. Diaz-Mitoma, A. Kumar, M. Kryworuchko, Amplification of the signal transducer and activator of transcription I signaling pathway and its association with apoptosis in monocytes from HIV-infected patients, AIDS Lond. Engl. 22 (2008) 1137-1144. doi:10.1097/QAD.0b013e3283013d42.

[127] Y. Takahashi, A.E. Mayne, L. Khowawisetsut, K. Pattanapanyasat, D. Little, F. Villinger, A.A. Ansari, In vivo administration of a JAK3 inhibitor to chronically siv infected rhesus macaques leads to NK cell depletion associated with transient modest increase in viral loads, PloS One. 8 (2013) e70992. doi:10.1371/journal.pone.0070992.

[128] Y. Takahashi, S.N. Byrareddy, C. Albrecht, M. Brameier, L. Walter, A.E. Mayne, P. Dunbar, R. Russo, D.M. Little, T. Villinger, L. Khowawisetsut, K. Pattanapanyasat, F. Villinger, A.A. Ansari, In vivo administration of a JAK3 inhibitor during acute SIV infection leads to significant increases in viral load during chronic infection, PLoS Pathog. 10 (2014) e1003929. doi:10.1371/journal.ppat.1003929.

[129] C. Gavegnano, M. Detorio, C. Montero, A. Bosque, V. Planelles, R.F. Schinazi, Ruxolitinib and tofacitinib are potent and selective inhibitors of HIV-1 replication and virus reactivation in vitro, Antimicrob. Agents Chemother. 58 (2014) 1977-1986.

doi:10.1128/AAC.02496-13. 
[130] W.B. Haile, C. Gavegnano, S. Tao, Y. Jiang, R.F. Schinazi, W.R. Tyor, The Janus kinase inhibitor ruxolitinib reduces HIV replication in human macrophages and ameliorates HIV encephalitis in a murine model, Neurobiol. Dis. 92 (2016) 137-143.

doi:10.1016/j.nbd.2016.02.007.

[131] A.M. Spivak, E.T. Larragoite, M.L. Coletti, A.B. Macedo, L.J. Martins, A. Bosque, V. Planelles, Janus kinase inhibition suppresses PKC-induced cytokine release without affecting HIV-1 latency reversal ex vivo, Retrovirology. 13 (2016) 88. doi:10.1186/s12977-016-0319-0.

[132] C. Gavegnano, J.H. Brehm, F.P. Dupuy, A. Talla, S.P. Ribeiro, D.A. Kulpa, C. Cameron, S. Santos, S.J. Hurwitz, V.C. Marconi, J.-P. Routy, L. Sabbagh, R.F. Schinazi, R.P. Sékaly, Novel mechanisms to inhibit HIV reservoir seeding using Jak inhibitors, PLoS Pathog. 13 (2017) e1006740. doi:10.1371/journal.ppat.1006740.

[133] L. Micci, J. Harper, S. Paganini, C. King, E. Ryan, F. Villinger, J. Lifson, M. Paiardini. Combined IL21 and IFN $\alpha$ treatment limits inflammation and delay viral rebound in ARTtreated, SIV infected macaques. Abstracts of the IAS HIV Cure and Cancer Forum 2017. No OA4-1. 


\section{ACKNOWLEDGEMENTS}

$\mathrm{NH}$ was recipient of a fellowship from the French Vaccine Research Institute funded by the National Agency of Research (ANR) under reference ANR-10-LABX-77. The Infectious Disease Models and Innovative Therapies (IDMIT) center in Fontenay-aux-Roses, France, is funded by the French government's Investissements d'Avenir program for infrastructures (PIA) under grant ANR-11-INBS0008 and the PIA grant ANR-10-EQPX-02-01. MMT received a grant from the French Agency of AIDS Research, ANRS (AO 2017-2) and a donation from the L'OREAL Foundation.

\section{FINANCIAL DISCLOSURE}

The authors declare that the research was conducted in the absence of any commercial or financial relationships that could be construed as a potential conflict of interest. 


\section{TABLES}

Table 1. Summary of the main studies using IFN-I in HIV patients

\begin{tabular}{|c|c|c|c|c|c|c|}
\hline $\begin{array}{l}\text { First } \\
\text { author }\end{array}$ & $\begin{array}{l}\text { Year of } \\
\text { publication }\end{array}$ & $\begin{array}{l}\text { Patients } \\
\text { characteristics }\end{array}$ & IFN type/dose & Main outcome & \multicolumn{2}{|c|}{ Key messages for development of future strategies } \\
\hline $\begin{array}{c}\text { deWit } \\
{[19]}\end{array}$ & 1988 & AIDS-KHSV & $\begin{array}{l}\text { IFN } \alpha 2 \mathrm{a}, 27-36 \\
\mathrm{MU} / \mathrm{d}, 8 \text { weeks } \\
\quad(\mathrm{n}=28)\end{array}$ & Reduction of HIV p24 & & \multirow{5}{*}{$\begin{array}{c}\text { No effect on overall } \\
\text { survival if administered } \\
\text { too late, deleterious if } \\
\text { already } \\
\text { immunocompromized }\end{array}$} \\
\hline $\begin{array}{l}\text { Lane } \\
\text { [20] }\end{array}$ & 1988 & AIDS-KHSV & $\begin{array}{l}\text { IFN } \alpha 2 b, 35 \mathrm{MU} / \mathrm{d} \text {, } \\
12 \text { weeks }(\mathrm{n}=21)\end{array}$ & Reduction of HIV p24 & & \\
\hline $\begin{array}{l}\text { Lane } \\
\text { [21] }\end{array}$ & 1990 & $\begin{array}{c}\text { Chronic } \\
\text { asymptomatic HIV } \\
\text { infection, CD4 > } \\
400 / \mathrm{mm} 3\end{array}$ & $\begin{array}{l}\text { IFN } \alpha 2 b, 35 \mathrm{MU} / \mathrm{d} \text {, } \\
12 \text { weeks }(\mathrm{n}=17) \\
\text { vs. Placebo }(\mathrm{n}=17)\end{array}$ & Reduction of HIV p24 & & \\
\hline $\begin{array}{l}\text { Rivero } \\
{[22,23]}\end{array}$ & 1994, 1997 & $\begin{array}{l}\text { Early stages of HIV } \\
\text { infection }\end{array}$ & $\begin{array}{l}\text { IFNa2b, } 3 \mathrm{MU} x \\
\text { 3/week ( } n=71) \text { vs. } \\
\text { placebo ( } n=79) \text {, } \\
\text { long term therapy }\end{array}$ & $\begin{array}{l}\text { Reduction of progression } \\
\text { towards AIDS, reduction } \\
\text { of AIDS-related } \\
\text { malignancies, better } 10- \\
\text { year survival rate }\end{array}$ & & \\
\hline Oka [27] & 1989 & $\begin{array}{l}\text { Early stages of HIV } \\
\text { infection }\end{array}$ & $\begin{array}{c}\text { IFN } \beta, 1 \mathrm{MU} x \\
\text { 2/week during } 6 \\
\text { months }(n=10)\end{array}$ & Few effect on HIV p24 & & \\
\hline $\begin{array}{l}\text { Miles } \\
{[28]}\end{array}$ & 1990 & AIDS-KHSV & $\begin{array}{l}\text { IFN } \beta, 90 \mathrm{MU} / \mathrm{d} \\
(\mathrm{n}=21) \text { vs. } 180 \\
\mathrm{MU} / \mathrm{d}(\mathrm{N}=18)\end{array}$ & $\begin{array}{l}\text { Few effect on the tumor } \\
\text { size and on HIV p24 (only } \\
\text { patients with the highest } \\
\text { basal viral load) }\end{array}$ & & \\
\hline $\begin{array}{l}\text { Miles } \\
{[30]}\end{array}$ & 1998 & AIDS-KHSV & $\begin{array}{c}\text { IFN } \beta, 22,5->90 \\
\text { MU/d (dose } \\
\text { escalation) + AZT }\end{array}$ & Few effect on tumor size & & \\
\hline $\begin{array}{l}\text { Asmuth } \\
\text { [36] }\end{array}$ & 2010 & $\begin{array}{c}\text { Chronic } \\
\text { asymptomatic HIV } \\
\text { infection, CD4 > } \\
\text { 300/mm3, ART } \\
\text { naïve (HIV VL > } \\
5000 / \mathrm{mL})\end{array}$ & $\begin{array}{c}\text { PEG-IFN } \alpha 2 a, 180 \\
\text { mcg/week, } 12 \\
\text { weeks }(n=11)\end{array}$ & $\begin{array}{l}\text { Transient and moderate } \\
\text { effect on viral load }(-0,6 \\
\text { log in median) }\end{array}$ & $\begin{array}{l}\text { Correlation with ISG inducibility, few } \\
\text { effect if high basal ISG expression } \\
\text { (linked with viral replication and } \\
\text { inflammation), no correlation with } \\
\text { PEG-IFN concentration }\end{array}$ & $\begin{array}{l}\text { Take into account basal } \\
\text { IFN-signature and } \\
\text { inflammatory disorders }\end{array}$ \\
\hline $\begin{array}{l}\text { Boue } \\
\text { [39] }\end{array}$ & 2011 & $\begin{array}{c}\text { Chronically infected } \\
\text { patients, } \\
\text { virologically } \\
\text { suppressed, CD4 > } \\
\text { 350/mm3, planned } \\
\text { for STI }\end{array}$ & $\begin{array}{c}\text { PEG-IFN } \alpha \text { during } \\
\text { STI }(1,5 \mu \mathrm{g} / \mathrm{kg} / \mathrm{w} \\
\text { during } 4 \text { weeks, } \\
\mathrm{n}=84) \text { vs. STI alone } \\
(\mathrm{n}=84)\end{array}$ & $\begin{array}{l}\text { No significant effect on } \\
\text { criteria for treatment } \\
\text { resumption }\end{array}$ & $\begin{array}{l}\text { CD4 T cell decline if low basal CD4 T } \\
\text { cells and/or high basal HIV DNA }\end{array}$ & $\begin{array}{l}\text { Better effect if reduction } \\
\text { of viral replication on }\end{array}$ \\
\hline $\begin{array}{l}\text { Goujard } \\
\text { [40] }\end{array}$ & 2012 & $\begin{array}{l}\text { ART during ongoing } \\
\text { primary infection, } \\
\text { planned for STI }\end{array}$ & $\begin{array}{c}\text { PEG-IFN } \alpha 2 b \text { ( } 1 \\
\mu g / k g / w) \text { during } \\
\text { STI }(n=30) \text { vs. STI } \\
\text { (n=31) vs. } \\
\text { Continuous ART } \\
(n=30)\end{array}$ & $\begin{array}{l}\text { No significant effect } \\
\text { compared with } \\
\text { continuous ART }\end{array}$ & $\begin{array}{l}\text { Predictive factors of poor response: } \\
\text { high viral DNA and RNA }\end{array}$ & ART \\
\hline $\begin{array}{c}\text { Azzoni } \\
{[41]}\end{array}$ & 2013 & $\begin{array}{l}\text { Chronically infected } \\
\text { patients, } \\
\text { virologically } \\
\text { suppressed on ART, } \\
\text { CD4 }>450 / \mathrm{mm} 3\end{array}$ & $\begin{array}{l}\text { PEG-IFN } \alpha 2 a \text { (90 or } \\
180 \mu g / \text { week) + } \\
\text { cART }(n=23)\end{array}$ & Reduction of HIV DNA & & $\begin{array}{l}\text { Take into account the } \\
\text { reservoir size }\end{array}$ \\
\hline
\end{tabular}

MU: million unit; d: day; ISG: Interferon stimulated genes 
Table 2. Overview of the major currently registred clinical trial evaluating the modulation of the IFN-pathway during HIV1-infection

\begin{tabular}{|c|c|c|c|c|c|c|c|c|c|}
\hline Concept & Number & Status & Title & Phase & Location & Patients & No patients & Therapeutic evaluation & Major endpoints \\
\hline $\begin{array}{l}\text { IFN } \\
\text { pathway } \\
\text { disruption }\end{array}$ & $\begin{array}{l}\text { NCT02475915 } \\
\text { NCT02079077 }\end{array}$ & $\begin{array}{l}\text { Completed } \\
\text { Active, not } \\
\text { recruiting }\end{array}$ & $\begin{array}{l}\text { Evaluating the Safety and Tolerability of } \\
\text { Ruxolitinib in Antiretroviral-Treated HIV- } \\
\text { Infected Adults } \\
\text { Efficacy of VHM After Treatment } \\
\text { Interruption in Subjects Initiating ART } \\
\text { During Acute HIV Infection } \\
\text { Inducing Immune Quiescence to Prevent } \\
\text { HIV Infection in Women (IIQ) }\end{array}$ & Phase 2 & $\begin{array}{l}\text { International, } \\
\text { multicentric } \\
\text { Thailand (SEARCH, } \\
\text { the Thai Red Cross } \\
\text { AIDS Research } \\
\text { Centre) }\end{array}$ & $\begin{array}{l}\text { HIV infected suppressed on cART for } \\
>2 \text { years, CD4 T cell > 350/mm3 } \\
\text { HIV infected patients, on ART since } \\
\text { acute infection, virologically } \\
\text { suppressed } \\
\text { HIV-negative sex workers vs. non sex } \\
\text { workers (Kenya) }\end{array}$ & Estimated: 60 & $\begin{array}{l}\text { Vorinostat-Hydroxychloroquine- } \\
\text { Maraviroc + cART vs. cART alone } \\
\text { Hydroxychloroquine: } 200 \mathrm{mg} / \text { day or } \\
\text { Acetylsalicylic acid } 81 \mathrm{mg} / \text { day }\end{array}$ & $\begin{array}{l}\text { Decrease in CD4, viral } \\
\text { blips, evaluation of the } \\
\text { safety } \\
\text { Proportion of patients } \\
\text { with HIV RNA < } 50 \\
\text { copies/ml following ART } \\
\text { interruption } \\
\text { Change in CD4 T cell } \\
\text { activation from baseline } \\
\text { at week } 8\end{array}$ \\
\hline $\begin{array}{l}\text { IFN- } \\
\text { pathway } \\
\text { induction }\end{array}$ & $\begin{array}{l}\text { NCT02858401 } \\
\text { NCT03060447 }\end{array}$ & $\begin{array}{l}\text { Recruiting } \\
\text { Active, not } \\
\text { recruiting }\end{array}$ & $\begin{array}{l}\text { Safety and Biological Activity of } \\
\text { Vesatolimod in HIV-1 Infected, } \\
\text { Virologically Suppressed Adults } \\
\text { Evaluate the Safety and Efficacy of } \\
\text { Vesatolimod in Antiretroviral Treated HIV- } \\
1 \text { Infected Controllers } \\
\text { Toll-like Receptor } 9 \text { Agonist Treatment in } \\
\text { Chronic HIV-1 Infection } \\
\text { Reducing the Residual Reservoir of HIV-1 } \\
\text { Infected Cells in Patients Receiving } \\
\text { Antiretroviral Therapy (ACTIVATE) } \\
\text { Safety and Immunogenicity of a Vaccine } \\
\text { Dendritic Cell-based Pulsed With } \\
\text { Autologous Heat-inactivated in HIV-1 } \\
\text { Infected Patients } \\
\text { Pilot Peg-Interferon-a2b in Decreasing } \\
\text { Viral DNA in HIV }\end{array}$ & Phase 1b & $\begin{array}{l}\text { Denmark (Aarhus) } \\
\text { USA (Boston, } \\
\text { Massachusetts } \\
\text { General Hospital } \\
\text { CRS) }\end{array}$ & $\begin{array}{l}\text { HIV infected patients, virologically } \\
\text { suppressed on cART for }>12 \text { months, } \\
\text { CD4 T cell }>400 / \mathrm{mm} 3 \\
\text { HIV infected patients, virologically } \\
\text { suppressed on cART for }>6 \text { months, } \\
\text { CD4 T cell }>450 / \mathrm{mm} 3 \\
\text { HIV infected patients, virologically } \\
\text { suppressed on cART for }>12 \text { months, } \\
\text { CD4 }>450 / \mathrm{mm} 3 \\
\text { HIV infected patients, virologically } \\
\text { suppressed on cART for }>12 \text { months, } \\
\text { CD4 }>450 / \mathrm{mm} 3\end{array}$ & Estimated: 25 & 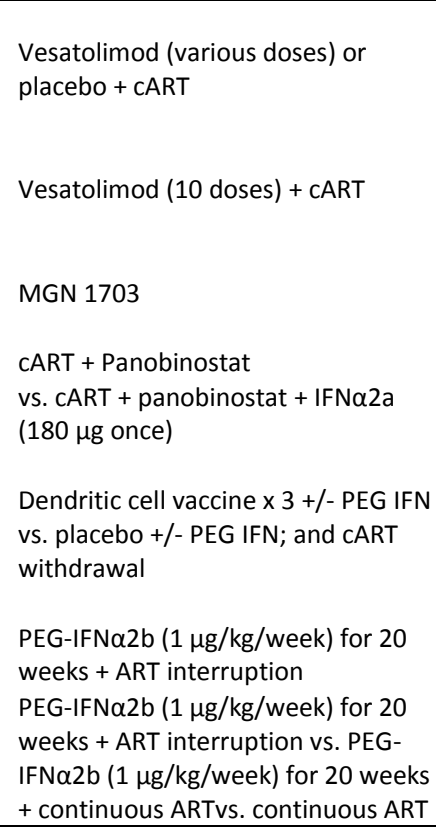 & $\begin{array}{l}\text { Occurrence of AE; Change } \\
\text { in CD4 T Cell-Associated } \\
\text { HIV-1 DNA from Baseline } \\
\text { Incidence of AE/SAE + } \\
\text { proportion of patients } \\
\text { with undetectable HIV VL } \\
\text { at } 12 \text { weeks } \\
\text { Changes from baseline } \\
\text { cellular HIV DNA at week } \\
24\end{array}$ \\
\hline
\end{tabular}

AE: adverse events. CART: combined antiretroviral therapy. PI: protease inhibitors. qVOA: quantitative viral outgrowth assay. SAE: serious adverse events

*: Pre-ART Plasma HIV-1 RNA set point between 50 and $\leq 5,000$ copies $/ \mathrm{mL}$ defining the "controller" status in this study 


\section{FIGURE LEGEND}

Figure 1. Anti-HIV strategies currently developed based on IFN-I. Representation of the strategies currently developed in the context of IFN-pathway activation during the different phases of HIV infection. During early phases and in some selected chronically infected patients with long-term viral control on ART (right side of the figure), the optimization of IFN-I agonism might be considered to gain insight in the reduction of HIV reservoirs. Therapeutics actually considered mainly consist in optimization of the IFN subtypes (ie, better administration of IFN $\alpha 2$ or IFN $\beta$, and other non- $\alpha 2$ IFN-I subtypes such as IFNa6, 8 or 14 , IFN $\lambda$, IFN $\varepsilon \ldots$...) or in the improvement of the endogenous IFN-I production using TLR agonists. The important question is the imbalance between antiviral effects and immune activation. During chronic phases of the infection (left side of the figure) in patients with persistent chronic inflammation, elevated IFN-signature and/or poor immunologic response despite good viral control, one objective might be the reduction of the IFN-enhanced immune activation using TLR antagonism (hydroxychloroquine), anti-IFNAR antibodies, and/or anti-JAK1/2 small molecules. All these strategies should be combined with ART to improve the control of the viral replication. See references [12], [13] and [18] for complete description of the IFN signaling pathway. IFN: Interferon; IFN-I: type I IFN; IRF: IFN-regulatory factor; IFNAR: IFN associated receptor; ISG: IFNstimulated genes; ISGF3: IFN-stimulated gene factor 3; ISRE: IFN-sensitive responsive element; STING: stimulator of IFN genes; STAT: Signal transducers and activators of transcription; TLR: Toll-like receptors. 
FIGURE 1

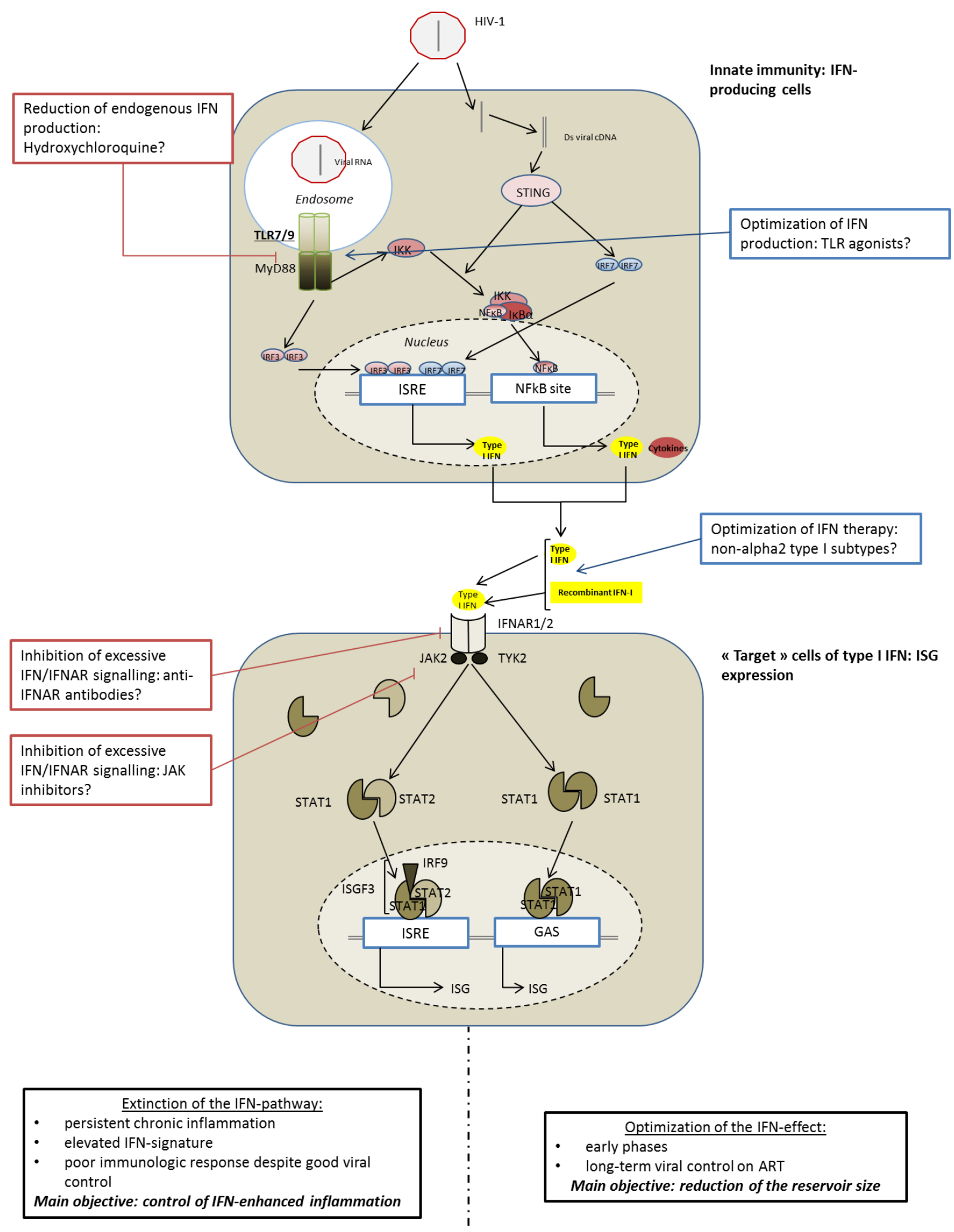




\section{Biographical Information}

\begin{tabular}{|c|c|}
\hline $\begin{array}{l}\text { Nicolas } \\
\text { Noël }\end{array}$ & $\begin{array}{l}\text { Nicolas Noël is currently MD in the Department of Internal Medicine and Clinical } \\
\text { Immunology at the Bicêtre Hospital (AP-HP). He received his Ph.D. in immunology } \\
\text { from the Université Paris Sud XI in 2014. He performed a post-doc on IFN-I in the } \\
\text { context of HIV infection at Institut Pasteur in 2016. He studies diseases affecting } \\
\text { several organs simultaneously (systemic diseases) or the defenses of the body } \\
\text { (immune or autoimmune diseases). }\end{array}$ \\
\hline $\begin{array}{l}\text { Beatrice } \\
\text { Jacquelin }\end{array}$ & $\begin{array}{l}\text { Beatrice Jacquelin obtained her PhD from University Paris Diderot. She has } \\
\text { performed pre-and post-doctoral internships at The Scripps Research Institute in La } \\
\text { Jolla, at the UMR } 5533 \text { CNRS (AT. Nurdens' laboratory) in Bordeaux and the CEA } \\
\text { (D. Tronik-Leroux laboratory), Genopole of Evry, France. She currently holds the } \\
\text { position as research engineer at Institut Pasteur in Paris. She is mainly interested in } \\
\text { the HIV-induced inflammation and uses animal models to search for the } \\
\text { mechanisms and ways to control it. }\end{array}$ \\
\hline $\begin{array}{l}\text { Nicolas } \\
\text { Huot }\end{array}$ & $\begin{array}{l}\text { Nicolas Huot obtained his Ph.D. in microbiology from the University Paris Sud XI by } \\
\text { studying HSV-1 latency. He performed a post-doctoral internship at IDMIT, CEA. He } \\
\text { is currently a postdoc fellow at the "HIV, Inflammation and Persistence" Unit at } \\
\text { Institut Pasteur in Paris, studying the role of NK cells in secondary lymphoid tissues } \\
\text { during SIV infection in natural hosts. }\end{array}$ \\
\hline $\begin{array}{l}\text { Cécile } \\
\text { Goujard }\end{array}$ & $\begin{array}{l}\text { Cecile Goujard is Professor in Internal Medicine, Head of Department of Internal } \\
\text { Medicine and Clinical Immunology at the Bicêtre Hospital (AP-HP). She is also a Co- } \\
\text { Investigator of the ANRS COPANA Cohort and ANRS PRIMO Cohort. }\end{array}$ \\
\hline $\begin{array}{l}\text { Olivier } \\
\text { Lambotte }\end{array}$ & $\begin{array}{l}\text { Olivier Lambotte is Professor in medicine in the Department of Internal Medicine } \\
\text { and Clinical Immunology at the Bicêtre Hospital (AP-HP). He is the head of one of } \\
\text { the research teams at the INSERM CEA UMR1184 Research Center on "Control of } \\
\text { chronic viral infections" . His areas of interest are inflammation, the links between } \\
\text { innate immunity and adaptive immunity and understanding of the control of HIV } \\
\text { infection especially in HIV-controller patients. }\end{array}$ \\
\hline $\begin{array}{l}\text { Michaela } \\
\text { Müller- } \\
\text { Trutwin }\end{array}$ & $\begin{array}{l}\text { Michaela Müller-Trutwin studied at the University in Bonn and Frankfurt and } \\
\text { obtained her PhD from Paris University in the Barré-Sinoussi lab. She holds the } \\
\text { position of Associate Professor and head of the "HIV, Inflammation and } \\
\text { Persistence" Unit at Institut Pasteur. She build up the Pasteur-Paris University } \\
\text { International PhD Program and was it's first Dean. She is the Chair of the ANRS } \\
\text { coordinated action on basic research on HIV. Her current interest is focused on } \\
\text { deciphering the early host innate immune responses during HIV and SIV infections } \\
\text { with the ultimate goal aim to provide novel insights for therapeutic and preventive } \\
\text { approaches. }\end{array}$ \\
\hline
\end{tabular}

